\title{
Mediterranean non indigenous species at the start of the 2020s: recent changes
}

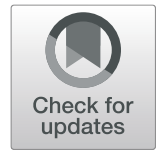

Argyro Zenetos $^{{ }^{*}}$ and Marika Galanidi ${ }^{2}$

\begin{abstract}
The current amendments to the Mediterranean marine Non-Indigenous Species (NIS) inventory for the period 2017-2019 are the result of a continuous literature search and update of the Hellenic Centre for Marine Research (HCMR) offline database. They take into account recent findings, previously missed records, backdated records based on the re-examination of existing material or phylogenetic studies and changes in nomenclature. During the period 2017-2019, 70 new species were added to the inventory of established species, 25 that had escaped our attention in the past and 23 newly introduced, which have already established self-sustaining populations. Meanwhile, 22 species previously known only with casual records have established viable populations and a total of 36 species have expanded their distribution into new Marine Strategy Framework Directive regions, primarily the Central Mediterranean and the Adriatic Sea. Intensified research efforts, prompted by the reporting obligations created by recent legislation, complemented by ever expanding networks and initiatives involving citizen scientists have certainly contributed to higher rates of discovery of alien species presences. However, the expansion of tropical and sub-tropical species into the cooler waters of the Aegean, the Adriatic and the western Mediterranean indicates that the warming of Mediterranean waters due to climate change is also facilitating the geographic expansion of NIS in the region. The rate of new introductions in this 3-year period is 8 species per year for the whole Mediterranean, without taking into account casual records or species with reporting lags. Only 4 species per year enter through the Suez Canal, while a considerable number of species are introduced through shipping vectors and the aquarium trade. Acknowledging the dynamic nature of invasions and the uncertainty inherent in compiling check lists, we consider the present work as the most accurate and up-to-date NIS list to inform policy, management and decision-making.
\end{abstract}

Keywords: Alien species, Mediterranean inventory, Updates, Range expansion

\section{Introduction}

Alien species inventories constitute a fundamental first step and a very important tool for the implementation of relevant policies and the delineation of management approaches (Vanderhoeven et al. 2017). They inform prioritization processes, e.g. Horizon Scanning (Roy et al. 2015; Tsiamis et al. 2020), the assessment of trends in introduction pathways (Korpinen et al. 2019) and the evaluation of existing management practices through the

\footnotetext{
* Correspondence: zenetos@hcmr.gr

${ }^{1}$ Hellenic Centre for Marine Research, Attiki, Greece

Full list of author information is available at the end of the article
}

calculation of suitable indicators (Armon and Zenetos 2015; Rabitsch et al. 2016).

As management efforts/policy initiatives to tackle alien and invasive species are intensified at the global and regional level (CBD (Convention on Biological Diversity) 2011; IMAP 2017), it is imperative that such inventories are regularly updated and remain current, especially since the introduction rate of new alien species globally does not appear to level off (Seebens et al. 2017 but see Zenetos 2019 for the Mediterranean), while their spread into new areas is facilitated by increasing volumes of trade and global transport networks (Latombe et al. 2017; Seebens et al. 2015).

(c) The Author(s). 2020 Open Access This article is licensed under a Creative Commons Attribution 4.0 International License, which permits use, sharing, adaptation, distribution and reproduction in any medium or format, as long as you give appropriate credit to the original author(s) and the source, provide a link to the Creative Commons licence, and indicate if changes were made. The images or other third party material in this article are included in the article's Creative Commons licence, unless indicated otherwise in a credit line to the material. If material is not included in the article's Creative Commons licence and your intended use is not permitted by statutory regulation or exceeds the permitted use, you will need to obtain permission directly from the copyright holder. To view a copy of this licence, visit http://creativecommons.org/licenses/by/4.0/. 
The inclusion of alien species descriptors and indicators in policy instruments has created reporting obligations at the national level (e.g. see Tsiamis et al. 2019) and triggered a surge of scientific activity dedicated to their detection, quantification, the exploration and mitigation of their impacts. Indicatively, the financial investments for alien species research and management have increased significantly in Europe since the early 1990s (Scalera 2010) and national monitoring schemes that cover NIS are in place in many Member States (ICES 2019). Additionally, Citizen Science (i.e. the involvement of the public in the production of scientific data - McKinley et al. 2017) has emerged as a powerful contributor to the early detection of new alien species as well as the surveillance of established invaders (Groom et al. 2019; Giovos et al. 2019) and novel genetic methods are more routinely employed, helping to clarify uncertainties with respect to species' identities and geographic origins (Bayha et al. 2017; Simon et al. 2019; Viard et al. 2019). As a result of this, the time lag between the first detection of a new alien species and the publication of the corresponding record has decreased in recent years, largely aided by the willingness of scientific journals to publish such biodiversity observations (Zenetos et al. 2019). The development of open data infrastructures, such as the European Alien Species Information Network (EASIN) (https://easin.jrc.ec.europa.eu/easin), that assure quality control of alien species information (Tsiamis et al. 2016) further enhances accessibility and analysis of the available information. The above notwithstanding, there are still information gaps and validation problems with alien species lists, that can only be overcome with the collaboration of local and taxonomic experts and the continuous update of regional/national databases. One such effort for Mediterranean marine alien species resulted in the critical revision and massive update of the alien species inventory for the Mediterranean Sea (Zenetos et al. 2017). In the current review, we build on that study and report recent changes in the marine Mediterranean xenodiversity since 2016, aiming to present a comprehensive and up-to-date NIS checklist at the closing of the previous decade.

\section{Methodology}

The work of Zenetos et al. (2017), including the published species list as well as the underlying database (HCMR offline database), forms the baseline for the current work. Updates are based on an extensive literature search, complemented by personal communications with local experts where needed, to verify alien status and establishment success.

Updates presented herein include: i). records of new alien species (AS) for the Mediterranean, reported after 2016;

ii). records of alien species published in the scientific literature but missing from comprehensive lists for the Mediterranean (including from the Zenetos et al. 2017 paper);

iii). species for which new literature until December 2019 (complemented by expert knowledge) reveals a change in their establishment success, most commonly from casual to established but also the reverse.

The terminology used in Zenetos et al. (2017) is also employed here, i.e. 'casual' denotes species reported once or twice on the basis of single individuals, whereas 'established' is used for species with multiple records, spread over time and place, regardless of evidence of reproductive success. Locally established species, i.e. species with established populations in one location only were also included in this category, with the rationale that they can constitute source populations for further expansion;

iv). species that have expanded their distribution into new areas [sensu MSFD: Marine Strategy Framework Directive (EC (European Commission) 2008)] since 2016;

v). species that, on the basis of genetic studies, taxonomic revisions, biogeographic reviews, etc. have changed alien status, i.e. are excluded from the aliens' list or move between the aliens, cryptogenic and Data Defficient categories (for a definition of the terms see Zenetos et al. (2010); Zenetos et al. (2017) and Tsiamis et al. (2019).

vi). nomenclature changes following updates in the World Register of Marine Species (WoRMS Editorial Board 2019);

vii).changes in year and/or country of first record based on recent literature backdating previous records (e.g. Aurelia solida Browne, 1905: Gueroun et al. 2020) as well as removing species from national lists as non-substantiated (e.g. Prionospio pulchra Imajima, 1990 in Italy: Servello et al. 2019);

Each species presented in the results section was assigned its most likely primary pathway of introduction or secondary spread, as appropriate. Pathway descriptions follow the Convention on Biological Diversity (CBD) definitions (CBD (Convention on Biological Diversity) 2014) and the relevant abbreviations are as follows: $\mathrm{CON}=$ TRANSPORT- CONTAMINANT, including Contaminant on animals (except parasites, species transported by host/vector) and Parasites on animals (including species transported by host and vector), COR = CORRIDOR: Interconnected waterways/basins/seas (in the current 
context this refers to the Suez Canal), ESC = ESCAPE FROM CONFINEMENT, referring to the accidental escape or intentional release of aquarium species (see IUCN (International Union for Conservation of Nature) 2017), T-S: TRANSPORT- STOWAWAY, including Ship/boat ballast water, Ship/boat hull fouling and Other means of transport, UNK = Unknown.

Mediterranean subregions are defined as per the MSFD delineation (Jensen et al. 2017), namely (a) the Western Mediterranean Sea (WMED); (b) the Ionian Sea and the Central Mediterranean Sea (CMED); (c) the Adriatic Sea (ADRIA); and (d) the Eastern Mediterranean Sea (EMED), encompassing the Aegean and Levantine basins. Country names are abbreviated according to the ISO 3166-1 alpha2 code system into a two-letter acronym.

\section{Results-discussion}

Excluding Foraminifera, a total of 666 established marine alien species are reported in the Mediterranean by December 2019 (Additional file 1). The continuous literature search and update of the HCMR offline database since December 2016 resulted in a total of 70 additions to the inventory of established marine alien species for the Mediterranean Sea (Additional file 1) and 112 new species in the Mediterranean NIS if casual records are considered. At the same time 16 species were deleted from the list (Additional file 2).

\section{Species to be removed from the established NIS inventory}

The presence of the bivalve mollusk Pseudochama corbierei (Jonas, 1846) in Greece was disputed by Crocetta et al. (2017). Its record in Israel is based on one shell from the beach (Barash and Danin 1972), while in Cyprus the record is not substantiated by a picture (Demetropoulos 1971). Therefore, the species is removed altogether from the list of Mediterranean NIS.

A new scyphozomedusa, sampled as bycatch in the Adriatic, was initially named by Piraino et al. (2014) as a new species, Pelagia benovici, and later placed in a new genus Mawia by Avian et al. (2016). Subsequently, Mawia was observed and sampled in several locations of the northern Adriatic and Ionian Sea (Chartosia et al. 2018). Bayha et al. (2017), in a comprehensive phylogenetic analysis of Pelagiidae, included two unidentified specimens collected from the west coast of Africa (Senegal), which genetic alanysis conclusively grouped together with $M$. benovici samples from the Adriatic. While this provides a potential source region for the species' introduction into the Mediterranean, the same study raises systematic questions about the phylogeny of the various species in the family and the erection of the new genus Mawia. Based on the discovery of paraphyly in the genus Chrysaora, Bayha et al. (2017) postulate that, in order to accept the validity of Mawia, as well as previously established Pelagia and Sanderia, additional genera would have to be erected within Pelagiidae in order to maintain monophyly of these generic groupings. Therefore, the species is assigned the Data Defficient status.

According to Faulwetter et al. (2017), the increasing discovery of cryptic species through molecular methods is creating uncertainty as to the diversity and distribution of polychaete species worldwide. Several of the of non-native polychaete species recorded in the Mediterranean were proven to be a complex of cryptic and pseudo-cryptic species. In these cases, it is likely that the name refers to a complex of cryptic species and Mediterranean material could belong to an overlooked native species, e.g Eurythoe complanata (Pallas, 1766), Lumbrineris perkinsi CarreraParra, 2001 that are now assigned to the cryptogenic category (Langeneck et al. 2020), Lezzi and Giangrande (2018) described from the Italian coast Streblosoma pseudocomatus which corresponds to Streblosoma comatus (Grube, 1859). Until there are further studies S. comatus is moved to the cryptogenic status.

A number of polychaete species that cannot be assigned to alien or cryptogenic status are classified as Data Defficient (Tsiamis et al. 2019). Such are the following seven polychaeta: Erinaceusyllis serratosetosa (Hartmann-Schröder, 1982), Hesionura serrata (Hartmann-Schröder, 1960), Metasychis gotoi (Izuka, 1902) Neanthes agulhana (Day, 1963), Neopseudocapitella brasiliensis Rullier \& Amoureux, 1979, Novafabricia infratorquata Fitzhugh, 1983; and Spirobranchus kraussii (Baird, 1865).

As an example, Simon et al. (2019) based on phylogenetic analysis of DNA concluded that $S$. kraussii is a warm temperate/subtropical intertidal species restricted to South African coasts. It belongs to a globally distributed complex including some tropical fouling and invasive species. Yet, it is believed that the records of $S$. kraussii from the Levantine might actually correspond to other species/strains of unknown identity (Elena K. Kupriyanova, pers. commun) but surely an alien for the Mediterranean.

\section{The revised check list of established NIS includes: Missing records}

Of these, 25 refer to species for which records pre-2017 had escaped our attention (missing records in Table 1). All these species are considered established but 9 of them are only established locally, i.e. they have documented populations in one location. The discovery of many of the missing records is owed to Servello et al. (2019), who confirmed the establishment of already recorded species in Italian waters, as well as to Abd ElRahman (2005) who studied the zooplankton of the Mediterranean coast of Egypt and confirmed the establishment of alien copepods. Other notable mentions 
Table 1 Established alien species reported before 2017 but missing from Zenetos et al. (2017)

\begin{tabular}{|c|c|c|c|}
\hline $\begin{array}{l}\text { Higher } \\
\text { taxon }\end{array}$ & Species & First record & Geographic expansion \\
\hline BRY & Celleporella carolinensis Ryland, 1979 & $\begin{array}{l}\text { 1993-IT: Occhipinti Ambrogi and } \\
\text { d'Hondt } 1996\end{array}$ & $\begin{array}{l}\text { locally established -see Servello et al. } \\
2019\end{array}$ \\
\hline BRY & Microporella browni Harmelin et al. 2011 & 2002-LB: Harmelin et al. 2011 & locally established \\
\hline BRY & Thalamoporella rozieri (Audouin, 1826) & 2002-LB: Harmelin 2014 & locally established \\
\hline $\mathrm{CNI}$ & Gonionemus vertens A. Agassiz, 1862 & 1918-IT: Joseph 1919 & $\begin{array}{l}\text { FR: Picard 1951/IT- see Servello et al. } \\
2019\end{array}$ \\
\hline $\mathrm{CNI}$ & $\begin{array}{l}\text { Scolionema suvaense (Agassiz \& Mayer, } \\
\text { 1899) }\end{array}$ & 1950-FR: Picard 1951 & IT: see Servello et al. 2019 \\
\hline $\mathrm{CNI}$ & Cassiopea andromeda (Forskål, 1775) & 1903-CY: Maas 1903 & GR, IL, IT, LB, MT, TN, TR -see EASIN \\
\hline CRU & $\begin{array}{l}\text { Acartia (Acanthacartia) fossae } \\
\text { Gurney, } 1927\end{array}$ & 1970s-LB: Lakkkis, 1976 & EG: Abd El-Rahman 2005 \\
\hline CRU & Acrocalanus gibber Giesbrecht, 1888 & 1966-LB: Lakkis 1990 & EG: Abd El-Rahman 2005 \\
\hline CRU & Arietellus pavoninus Sars G.O., 1905 & $\begin{array}{l}\text { 1967-GR: Moraitou-Apostolopoulou } \\
1969\end{array}$ & EMED: Zenetos et al. 2010 \\
\hline CRU & Centropages furcatus (Dana, 1849) & 1989-LB: Lakkis 1990 & EG, GR,TR, LB-see EASIN \\
\hline CRU & Labidocera madurae Scott A., 1909 & 1970s-LB: Lakkis 1976 & EG: Abd El-Rahman 2005/TR: Lakkis et al. 2005 \\
\hline CRU & Paracartia grani Sars G.O., 1904 & 1975-ES: Bradford-Grieve 1999 & FR, GR, IT, LB, SY, TN, TR- see EASIN \\
\hline CRU & Triconia rufa (Boxshall \& Böttger, 1987) & 1982-LB: Malt et al. 1989 & $\begin{array}{l}\text { IT: see Servello et al. 2019/EG: Abd El-Rahman } \\
2005\end{array}$ \\
\hline CRU & $\begin{array}{l}\text { Triconia umerus (Böttger-Schnack \& } \\
\text { Boxshall, 1990) }\end{array}$ & $\begin{array}{l}\text { 2004-IT: Di Capua and Boxshall } \\
2008\end{array}$ & locally established -see Servello et al. 2019 \\
\hline CRU & Livoneca redmanii Leach, 1818 & <2015-EG: Rania and Rehab 2015 & locally established -see Abdel-Latif 2016 \\
\hline CRU & $\begin{array}{l}\text { Mesanthura cf. romulea Poore \& } \\
\text { Lew Ton, } 1986\end{array}$ & <1989-EG: Samaan et al. 1989 & CY, ES, GR, IT, MT, TN, TR-see Ulman et al. 2017 \\
\hline CRU & Synidotea variegata Collinge, 1917 & 1983-84-EG: Ramadan 1986 & locally established -see Ramadan et al. 1998 \\
\hline CRU & Neomysis integer (Leach, 1814) & 1939-FR: Băsescu 1941 & ES: Munilla and San 2005 \\
\hline CRU & $\begin{array}{l}\text { Megabalanus tintinnabulum } \\
\text { (Linnaeus, 1758) }\end{array}$ & $\begin{array}{l}\text { 1791-IT: Poli } 1791 \text { as Lepas balanus } \\
\text { Linnaeus, } 1758\end{array}$ & DZ, EG, GR, HR, IL, MT, SI -see EASIN \\
\hline $\mathrm{MOL}$ & Lottia sp. Gray, 1833 & 2015-IT: Scuderi and Eernisse 2016 & locally established -see Servello et al. 2019 \\
\hline $\mathrm{MOL}$ & Nerita sanguinolenta Menke, 1829 & 1969-GR: Nordsieck 1973 & EG, LY, TN, TR-see EASIN \\
\hline $\mathrm{RHO}$ & Caulacanthus okamurae Yamada & 2004-FR: Mineur et al. 2007 & FR: confirmed by M. Verlaque \\
\hline $\mathrm{RHO}$ & $\begin{array}{l}\text { Diplothamnion jolyi C. van den } \\
\text { Hoek, } 1978\end{array}$ & 2012-MA: Moussa et al. 2015 & locally established \\
\hline $\mathrm{RHO}$ & $\begin{array}{l}\text { Spermothamnion cymosum (Harvey) } \\
\text { De Toni }\end{array}$ & 2010-IT: Armeli 2013 & locally established -see Servello et al. 2019 \\
\hline SIP & $\begin{array}{l}\text { Phascolosoma scolops (Selenka \& } \\
\text { de Man, 1883) }\end{array}$ & 1975-HR: Murina 1976 & CY: Açik et al. 2005 \\
\hline
\end{tabular}

Abbreviations for taxonomic groups are as follows: BRY Bryozoa, CNI Cnidaria, CRU Crustacea, MOL Mollusca, RHO Rhodophyta, SIP Sipuncula. Country codes follow the internationally accepted two-letter codes for countries (https://www.worldatlas.com/aatlas/ctycodes.htm)

include Paracartia grani Sars G.O., 1904, a species that was previously assigned cryptogenic status but has now been reinstated as alien (see Tsiamis et al. 2019) and the parasite Livoneca redmanii Leach, 1818, which was found parasitizing Argyrosomus regius in Egyptian waters (Rania and Rehab 2015).

Cassiopea andromeda (Forskål, 1775), a long-established species in the Mediterranean (e.g. see Maggio et al. 2019), is included here to rectify an omission in the Zenetos et al. (2017) inventory. The same applies for the copepod Arietellus pavoninus Sars G.O., 1905, already established in the eastern Mediterranean, which was included in Zenetos et al. (2010) but was missed in Zenetos et al. (2017). If records of foraminifera were included in this list, the number would be much higher, however we opted to exclude them from the current work as the particular taxonomic group is due for a revision of its native/ alien species in a comprehensive article (Langer, in preparation). 
Table 2 New NIS reported in the 2017-19 period. In bold established NIS

\begin{tabular}{|c|c|c|c|c|c|c|}
\hline $\begin{array}{l}\text { Higher } \\
\text { taxon }\end{array}$ & Species name & $\begin{array}{l}\text { Year of 1st } \\
\text { Introduction }\end{array}$ & $\begin{array}{l}\text { Country of 1st } \\
\text { introduction }\end{array}$ & $\begin{array}{l}\text { Establishment } \\
\text { success }\end{array}$ & $\begin{array}{l}\text { Potential } \\
\text { Pathway }\end{array}$ & Source \\
\hline ASC & Ascidia aff. curvata (Traustedt, 1882) & 2014-15 & $\mathrm{IL}$ & cas & UNK & Gewing and Shenkar 2017 \\
\hline ASC & $\begin{array}{l}\text { Botrylloides diegensis Ritter and Forsyth, } \\
1927\end{array}$ & unk & unk & est & UNK & Viard et al. 2019 \\
\hline BRY & $\begin{array}{l}\text { Calyptotheca alexandriensis } \\
\text { Abdel-salam et al. } 2017\end{array}$ & 2015 & EG & est & COR & Abdelsalam et al. 2017 \\
\hline $\mathrm{CHL}$ & $\begin{array}{l}\text { Codium pulvinatum M.J.Wynne \& } \\
\text { R.Hoffman }\end{array}$ & 2014 & $\mathrm{IL}$ & est & COR & Hoffman et al. 2017 \\
\hline $\mathrm{CHL}$ & $\begin{array}{l}\text { Avrainvillea amadelpha (Montagne) } \\
\text { A.Gepp \& E.S.Gepp }\end{array}$ & 2012 & LY & est & T-S & Verlaque et al. 2017 \\
\hline $\mathrm{CHL}$ & Ulva tepida Masakiyo \& S.Shimada, 2014 & 2002 & IL & unk & $\mathrm{T}-\mathrm{S} / \mathrm{COR}$ & Krupnic et al., 2018 \\
\hline $\mathrm{CHL}$ & Ulva chaugulii M.G.Kavale \& M.A.Kazi & 2015-16 & $\| \mathrm{L}$ & unk & $\mathrm{T}-\mathrm{S} / \mathrm{COR}$ & Krupnic et al., 2018 \\
\hline $\mathrm{CNI}$ & Cotylorhiza erythraea Stiasny, 1920 & 2003 & $\mathrm{IL}$ & est & COR & Galil et al. 2017a \\
\hline $\mathrm{CNI}$ & $\begin{array}{l}\text { Chrysaora cf. achlyos Martin, Gershwin, Burnett, } \\
\text { Cargo and Bloom, } 1997\end{array}$ & 2018 & GR & unk & T-S & Langeneck et al. 2019 \\
\hline CRU & Stenothoe georgiana Bynum \& Fox, 1977 & 2010 & ES & est & $\mathrm{CON}$ & $\begin{array}{l}\text { Fernandez-Gonzalez and } \\
\text { Sanchez-Jerez } 2017\end{array}$ \\
\hline CRU & $\begin{array}{l}\text { Hatschekia siganicola El-Rashidy \& Boxshall, } \\
2011\end{array}$ & 2016 & LY & unk & CON & Abdelnor et al. 2019 \\
\hline CRU & Arcania brevifrons Chen, 1989 & 2016 & $\mathrm{IL}$ & est & COR & Galil et al. 2017b \\
\hline CRU & Lysmata vittata (Stimpson, 1860) & 2017 & EG & cas & COR & Abdelsalam 2018 \\
\hline CRU & $\begin{array}{l}\text { Panulirus longipes longipes (A. Milne-Edwards, } \\
\text { 1868) }\end{array}$ & 2018 & IL & cas & ESC & $\begin{array}{l}\text { Spanier and Friedmann } \\
2019\end{array}$ \\
\hline CRU & Dioithona oculata (Farran, 1913) & 2013 & TR & est & T-S & Terbıyık Kurt 2018 \\
\hline CRU & Aoroides longimerus Ren \& Zheng, 1996 & 2015 & FR & unk & T-S & Ulman et al. 2017 \\
\hline CRU & Cymodoce fuscina Schotte \& Kensley, 2005 & 2002 & LB & est & T-S & Castelló et al. 2020 \\
\hline CRU & Xiphopenaeus kroyeri (Heller, 1862) & 2016 & EG & est & T-S & Khafage and Taha 2019 \\
\hline CRU & Laticorophium baconi (Shoemaker, 1934) & 2018 & ES & unk & T-S & Gouillieux and Sauriau 2019 \\
\hline CRU & Pleopis schmackeri (Poppe, 1889) & 2012 & $\mathrm{TR}$ & est & UNK & $\begin{array}{l}\text { Terbıyık Kurt and Polat } \\
2017\end{array}$ \\
\hline CRU & $\begin{array}{l}\text { Pseudodiaptomus trihamatus Wright S., } \\
1937\end{array}$ & 2014 & EG & est & UNK & Eltohamy et al. 2017 \\
\hline $\mathrm{ECH}$ & $\begin{array}{l}\text { Holothuria (Theelothuria) hamata Pearson, } \\
1913\end{array}$ & 2017 & TR & cas & $\mathrm{COR}$ & Aydin et al. 2019 \\
\hline FISH & Fistularia petimba Lacepède, 1803 & 2016 & IL & est & $\mathrm{COR}$ & Stern et al. 2017 \\
\hline FISH & Priacanthus prolixus Starnes, 1988 & 2016 & TR & cas & COR & Gürlek et al. 2017 \\
\hline FISH & $\begin{array}{l}\text { Bathygobius cyclopterus (Cuvier \& } \\
\text { Valenciennes 1837) }\end{array}$ & 2017 & EG & cas & COR & Akel In Stamouli et al. 2017 \\
\hline FISH & Acanthurus sohal (Forsskål, 1775) & 2017 & GR & cas & $\mathrm{COR}$ & Giovos et al. 2018 \\
\hline FISH & $\begin{array}{l}\text { Arnoglossus nigrofilamentosus } \\
\text { Fricke et al. } 2017\end{array}$ & 2017 & IL & cas & COR & Fricke et al. 2017 \\
\hline FISH & Caesio varilineata Carpenter, 1987 & 2018 & EG & est & COR & Bos and Ogwang 2018 \\
\hline FISH & Ablennes hians (Valenciennes, 1846) & 2018 & $\mathrm{IL}$ & cas & COR & $\begin{array}{l}\text { Golani 2019/Alshawy et al. } \\
\text { 2019a }\end{array}$ \\
\hline FISH & Chaetodon auriga Forsskål, 1775 & 2015 & IT & cas & ESC & Tiralongo et al. 2018 \\
\hline FISH & Abudefduf sexfasciatus (Lacepède, 1801) & 2017 & $G R$ & cas & ESC & Giovos et al. 2018 \\
\hline $\mathrm{FISH}$ & Chrysiptera hemicyanea (Weber, 1913) & 2017 & MT & cas & ESC & Deidun et al. 2018 \\
\hline FISH & Arothron hispidus (Linnaeus, 1758) & 2018 & $C Y$ & cas & ESC & Bariche et al. 2018 \\
\hline FISH & Variola louti (Forsskål, 1775) & 2018 & $C Y$ & cas & ESC & $\begin{array}{l}\text { Huseyinoglu \& Jimenez, in } \\
\text { Kousteni et al. } 2019\end{array}$ \\
\hline
\end{tabular}


Table 2 New NIS reported in the 2017-19 period. In bold established NIS (Continued)

\begin{tabular}{|c|c|c|c|c|c|c|}
\hline $\begin{array}{l}\text { Higher } \\
\text { taxon }\end{array}$ & Species name & $\begin{array}{l}\text { Year of 1st } \\
\text { Introduction }\end{array}$ & $\begin{array}{l}\text { Country of 1st } \\
\text { introduction }\end{array}$ & $\begin{array}{l}\text { Establishment } \\
\text { success }\end{array}$ & $\begin{array}{l}\text { Potential } \\
\text { Pathway }\end{array}$ & Source \\
\hline FISH & Bodianus speciosus (Bowdich, 1825) & 2018 & TR & cas & ESC & Filiz et al. 2019 \\
\hline FISH & Heteropriacanthus cruentatus (Lacepède, 1801) & 2019 & LB & cas & $\mathrm{ESC} / \mathrm{COR}$ & Badreddine and Bitar 2019 \\
\hline FISH & Holacanthus africanus Cadenat, 1951 & 2017 & MT & cas & T-S & Deidun et al. 2017 \\
\hline FISH & Diplogrammus randalli Fricke, 1983 & 2016 & TR & cas & $\mathrm{T}-\mathrm{S} / \mathrm{COR}$ & Seyhan et al. 2017 \\
\hline FISH & Dipterygonotus balteatus (Valenciennes, 1830) & 2017 & LB & cas & $\mathrm{T}-\mathrm{S} / \mathrm{COR}$ & Bariche and Fricke 2018 \\
\hline FISH & Apogon atradorsatus Heller \& Snodgrass, 1903 & 2019 & SY & cas & $\mathrm{T}-\mathrm{S} / \mathrm{COR}$ & Alshawy et al. 2019b \\
\hline FISH & Encrasicholina punctifer Fowler, 1938 & 2014 & TR & cas & UNK & Çiftçi et al. 2017 \\
\hline FISH & Chlorurus rhakoura Randall \& Anderson, 1997 & 2017 & IT & cas & UNK & Insacco and Zava 2017 \\
\hline MAM & Sousa plumbea (G. Cuvier, 1829) & 2016 & TR & unk & UNK & Ozbilgin et al. 2018 \\
\hline MOL & Crithe cossinea T. Cossignani, 1997 & 2014 & TR & cas & COR & Aslan and Ovalis 2017 \\
\hline $\mathrm{MOL}$ & Viriola sp.[cf. bayani] Jousseaume, 1884 & 2016 & GR & est & COR & Micali et al. 2017 \\
\hline $\mathrm{MOL}$ & Rugalucina vietnamica (Zorina, 1978) & 2016 & $\mathrm{IL}$ & cas & $\mathrm{COR}$ & Steger et al. 2018 \\
\hline MOL & Alveinus miliaceus (Issel, 1869) & 2016 & $\mathrm{IL}$ & est & COR & Steger et al. 2018 \\
\hline MOL & Gari pallida (Deshayes, 1855) & 2017 & $\mathrm{IL}$ & cas & COR & Lubinevsky et al. 2018 \\
\hline $\mathrm{MOL}$ & Gregariella cf. ehrenbergi (Issel, 1869) & 2014 & EG & est & T-S & Steger et al. 2018 \\
\hline $\mathrm{MOL}$ & Euthymella colzumensis (Jousseaume, 1898) & 2017 & GR & unk & $\mathrm{T}-\mathrm{S} / \mathrm{COR}$ & $\begin{array}{l}\text { Angelidis and Polyzoulis } \\
2018\end{array}$ \\
\hline MOL & Phidiana militaris (Alder \& Hancock, 1864) & 2016 & $\mathrm{IL}$ & cas & UNK & Rothman et al. 2017 \\
\hline MOL & Varicopeza pauxilla (A. Adams, 1855) & 2016 & TR & est & UNK & Öztürk et al. 2017 \\
\hline PAN & Achelia sawayai s.l. Marcus, 1940 & 2016 & $\mathrm{IT}, \mathrm{MT}$ & est & T-S & Ulman et al. 2017 \\
\hline $\mathrm{PHY}$ & Chaetoceros pseudosymmetricus Nielsen, 1931 & 2015 & $\mathrm{HR}$ & unk & UNK & Čalić et al. 2018 \\
\hline PLAT & Pseudempleurosoma sp Yamaguti, 1965 & 2012 & $\mathrm{TN}$ & un & CON & Boussellaa et al. 2018 \\
\hline PLAT & $\begin{array}{l}\text { Aponurus sigani Abdel Aal, Banaja \& Al- } \\
\text { Zanbagi, } 1984\end{array}$ & 2016 & LY & unk & CON & Abdelnor et al. 2019 \\
\hline PLAT & Pseudoceros duplicinctus Prudhoe, 1989 & 2015 & $\mathrm{IL}$ & unk & UNK & Velasquez et al. 2018 \\
\hline PLAT & Pseudobiceros stellae Newman \& Cannon, 1994 & 2016 & $\mathrm{IL}$ & unk & UNK & Velasquez et al. 2018 \\
\hline POL & Boccardia proboscidea Hartman, 1940 & 2014 & FR & cas & CON & Radashevsky et al. 2019 \\
\hline POL & Iphione muricata (Lamarck, 1818) & 2015 & IL & est & COR & Goren et al. 2017 \\
\hline POL & Caulleriella viridis (Langerhans, 1881) & 2006 & $G R$ & que & T-S & Maidanou et al. 2017 \\
\hline $\mathrm{RHO}$ & $\begin{array}{l}\text { Aglaothamnion hallia (Collins) Aponte, D.L. } \\
\text { Ballantine \& J.N. Norris }\end{array}$ & 2016 & IT & cas & CON & Wolf et al. 2018 \\
\hline $\mathrm{RHO}$ & $\begin{array}{l}\text { Melanothamnus japonicus (Harvey) Díaz- } \\
\text { Tapia \& Magg }\end{array}$ & 2016 & IT & est & CON & Wolf et al. 2018 \\
\hline $\mathrm{RHO}$ & $\begin{array}{l}\text { Kapraunia schneideri (Stuercke \& } \\
\text { Freshwater) A.M.Savoie \& G.W.Saunders }\end{array}$ & 2016 & IT & est & T-S & Wolf et al. 2018 \\
\hline TRA & Halophila decipiens Ostenfeld & 2018 & GR & est & T-S & Gerakaris et al. 2020 \\
\hline
\end{tabular}

Taxonomic group abbreviations: ASC Ascidiacea, BRY Bryozoa, CHL Chlorophyta, CNI Cnidaria, CRU Crustacea, ECH Echinodermata, FISH Fishes, MAM Mammals, MOL Mollusca, PAN Pantopoda, PHY Phytoplankton, PLAT Platyelminthes, POL Polychaeta, RHO Rhodophyta, TRA Tracheophyta. The Pathway column indicates the most likely primary pathway of Introduction: CON TRANSPORT- CONTAMINANT, COR CORRIDOR, ESC ESCAPE FROM CONFINEMENT, T-S TRANSPORT- STOWAWAY, UNK Unknown. Country codes follow the internationally accepted two-letter codes for countries https://www.worldatlas.com/aatlas/ctycodes.htm)

\section{New species}

In the period 2017-2019, 65 new NIS species have been reported (Table 2) of which 23 are established. In cases where the establishment status of the species was not clear from the literature, confirmation was sought from experts: i.e. for the alga Codium pulvinatum M.J.Wynne
\& R. Hoffman and the polychaete Iphione muricata (Lamarck, 1818), which are both established in Israel (pers. comm. by Razy Hoffman and Liron Goren respectively). The record of the polychaete Boccardia proboscidea Hartman, 1940 in France must be treated with caution. The French specimen was retrieved from an oyster at a 
restaurant in southern France, with a putative origin in the main aquaculture facility of the nearby Leucate lagoon (Radashevsky et al. 2019). However, due to the high uncertainty associated with the origins of the oyster specimen, this finding requires confirmation and further investigation before a sound Mediterranean record is established (Radashevsky et al. 2019). Approximately one third $(1 / 3)$ of the recently reported species are demersal fishes, the majority of which have presumably entered either via the Suez Canal or are aquaria releases; nevertheless, the additions include representatives from a broad range of taxonomic groups.

All new established NIS were observed after 2012, with the exception of Botrylloides diegensis Ritter and Forsyth, 1927, Ulva tepida Masakiyo \& S. Shimada, 2014 and Cotylorhiza erythraea Stiasny, 1920. Ulva tepida was collected in Israel in 2002 and then again in 2015-2016 but was only conclusively identified with genetic markers and reported in 2018 (Krupnik et al. 2018). The same study reported $U$. chaugulii for the first time from the Mediterranean in 2015-2016, although the authors point out that, due to the high phenotypic plasticity of Ulva species, earlier records of $U$. linza Linnaeus (see Einav and Israel 2008) may represent one or both of these species (Krupnik et al. 2018). The establishment success of both $U$. tepida and $U$. chaugulii is currently unknown. Concerning $B$. diegensis, Viard et al. (2019), based on genetic studies and a re-examination of GenBank sequences from various Mediterranean locations, propose that the presence of this species may have been strongly underestimated in the Mediterranean region, as it is commonly confused for Botrylloides leachii (Savigny, 1816), such that its year and location of first introduction cannot be easily ascertained. Cotylorhiza erythraea on the other hand, has been observed off the Israeli coast since 2003 but its identity was only recently confirmed with the help of molecular analyses (Galil et al. 2017a). Not surprisingly, the countries with the highest number of newly recorded and established NIS were Israel (17 species in total / 6 established), Turkey (10/3) and Egypt (7/5). Nevertheless, the Suez Canal (i.e. the corridor pathway) is not the only important pathway of introduction for new species $(n=19+7)$, where 19 is the number of species whose introduction is attributed exclusively to the corridor pathway and 7 are the species which could have entered also via alternative pathways. The transport-stowaway (T-S) pathway, representing ships ballast, hull fouling and other vectors, contributed almost equally to new species introductions reported in the 2017-2019 period $(n=13+6)$, where 13 is the number of species whose introduction is attributed exclusively to the T-S pathway and 6 are the species which could have entered also via alternative pathways, while escape from confinement of pet species from aquaria (ESC) and transport-contaminant $(\mathrm{CON})$, both as parasites and as hitchhikers on aquaculture transports, are considered responsible for the introduction of 8 and 7 new species respectively. Finally, the primary pathway of introduction remains undetermined for 12 of the 65 new species.

\section{Species that have changed their establishment success}

Twenty two species previously considered as casual records have established viable populations (Table 3). The time spans between consecutive records for the species of this category vary considerably but are as long as 5090 years in some cases. The amphipod Bemlos leptocheirus, recorded for the first time near the entrance of the Suez Canal almost a century ago (Schellenberg 1928), reappeared in the Mediterranean in 2015, recorded by Ulman et al. (2017) in two Greek marinas, and is now considered established. The bryozoan Hippopodina sp has been sporadically reported from the Eastern Mediterranean Sea as $H$. feegensis (Busk, 1884) since 1966 (Powell 1969). The species was recently re-described by Tilbrook (1999), leading Ulman et al. (2017) to conclude that the specimens found in Turkish and Greek marinas belong to the yet undescribed Hippopodina sp. collected by Tilbrook (2006) from Massawa Harbor, Erythraea (K. J. Tilbrook, 2017, personal communication in Ulman et al. 2017). Previous records of $H$. feegensis in Rodos, Greece (Corsini-Foka et al. 2015) may need to be re-examined and re-assigned to Hippopodina sp. A (Ulman et al. 2017). The bivalve Isognomon legumen (Gmelin, 1791), which is now considered established on the basis of new and re-examined records, constitutes another case of difficult identification/misidentification. First reported in Israel by Mienis et al. (2016), the species' presence is now confirmed from multiple locations in Greece, Turkey and Italy (Crocetta et al. 2017; Micali et al. 2017; Stamouli et al. 2017; Scuderi and Viola 2019). The opisthobranch Berthellina citrina (Rüppell \& Leuckart, 1828), which was previously excluded from alien species lists of the Mediterranean (Zenetos et al. 2004) due to possible misidentifications with the native Berthellina edwardsii (Vayssière, 1897) (Cervera et al. 2004), has now been identified by molecular analysis and reported from three different locations in southern Turkey (Yokeş et al. 2018). Genetic analyses were also instrumental in verifying the presence of the pomacentrid Abudefduf vaigiensis (Quoy \& Gaimard, $1825)$ in the Mediterranean Sea, which had been excluded from the list of established species in Zenetos et al. (2017), after it was concluded by Tsadok et al. (2015) that the population in Israel actually belonged to $A$. saxatilis. Since then, established populations of $A$. vaigiensis have been reported from Malta (Vella et al. 2016) and 
Table 3 Alien Species that became established in the 2017-2019 period

\begin{tabular}{|c|c|c|c|}
\hline Higher taxon & Species name & Original source & Additional sources \\
\hline BRY & Hippopodina sp. & 1966-IL: Powell 1969 & 1996-GR: Morri et al. 1999 / 2016-TR: Ulman et al. 2017 \\
\hline BRY & Watersipora arcuata Banta, 1969 & 2013-IT: Ferrario et al. 2015 & 2016-TR, ES, MT, IT: Ulman et al. 2017 \\
\hline $\mathrm{CNI}$ & Oulastrea crispata (Lamarck, 1816) & $\begin{array}{l}\text { 2012-FR: Hoeksema \& Ocaña } \\
\text { Vicente, } 2014\end{array}$ & 2017-ES: Mariani et al. 2018 \\
\hline CRU & Bemlos leptocheirus (Walker, 1909) & 1924-EG: Schellenberg 1928 & 2015-GR: Ulman et al. 2017 \\
\hline CRU & Charybdis feriata (Linnaeus, 1758) & 2004-ES: Abelló and Hispano 2006 & $\begin{array}{l}\text { 2015-IT: Tiralongo in Karachle et al. 2016/ 2017-ES: } \\
\text { Colmenero et al. } 2019\end{array}$ \\
\hline CRU & $\begin{array}{l}\text { Cymothoa indica Schioedte \& Meinert, } \\
1884\end{array}$ & 2003-LB: Trilles and Bariche 2006 & <2015-EG: Rania and Rehab 2015 \\
\hline CRU & Halimede ochtodes (Herbst, 1783) & 2013-EG: Moussa et al. 2016 & 2013-EG: Akel in Lipej et al. 2017 \\
\hline CRU & Halimede tyche (Herbst, 1801) & 1998-IL: Galil 2000 & 2016-LB: SPA/RAC-UN Environment/MAP 2017 \\
\hline CRU & laniropsis serricaudis Gurjanova, 1936 & 2012-IT: Marchini et al. 2016 & 2014-IT: Ferrario et al. 2017/2015-FR: Ulman et al. 2017 \\
\hline CRU & Oithona davisae Ferrari F.D. \& Orsi, 1984 & 2000-ES: Saiz et al. 2003 & $\begin{array}{l}\text { 2004-5-IT: Zagami et al. } 2018 \text { / 2015-TR: Terbıyık Kurt } \\
\text { and Beşiktepe } 2019 \text { 2018- GR: Anadoli \& Michaloudi, in } \\
\text { Dragicevic et al., } 2019\end{array}$ \\
\hline CRU & Sicyonia lancifer (Olivier, 1811) & 2015-TR: Gönülal et al. 2016 & IL-Galil \& Lubinevsky in Stern et al. 2019 \\
\hline FISH & $\begin{array}{l}\text { Abudefduf vaigiensis (Quoy \& Gaimard, } \\
\text { 1825) }\end{array}$ & 1957-IT: Tardent 1959 & 2013-MT: Vella et al. 2016 / 2018-LY: Osca et al. 2020 \\
\hline FISH & Ostracion cubicus Linnaeus, 1758 & 2011-LB: Bariche 2011 & 2017-TR: Gökoğlu \& Korun in Gerovasileiou et al. 2017 \\
\hline FISH & Pomacanthus imperator (Bloch, 1787) & 2009-IL: Golani et al. 2010 & $\begin{array}{l}\text { 2017-SY: Capapé et al. 2018a; Saad et al. } 2018 \text { / 2019-TR: } \\
\text { Gürlek et al. } 2019 \text { /2015-19-IL: Rothman \& Stern in } \\
\text { Stern et al. } 2019\end{array}$ \\
\hline $\mathrm{MOL}$ & Baeolidia moebii Bergh, 1888 & 2007-TR: Turk and Furlan 2011 & 2017-CY: Paz-Sedano et al. 2019 \\
\hline $\mathrm{MOL}$ & $\begin{array}{l}\text { Berthellina citrina (Rüppell \& Leuckart, } \\
\text { 1828) }\end{array}$ & $\begin{array}{l}\text { 1940-PA: O'Donoghue and White } \\
1940\end{array}$ & 2005-TR: Yokes \& Ünsal Karhan in Yokes et al., 2018 \\
\hline $\mathrm{MOL}$ & Cuthona perca (Er. Marcus, 1958) & 1976-IT: Cesari 1994 & 2015-SI: Lipej \& Trkov in Yokeş et al. 2018 \\
\hline $\mathrm{MOL}$ & $\begin{array}{l}\text { Goniobranchus obsoletus (Rüppell \& } \\
\text { Leuckart, 1830) }\end{array}$ & 2015-IL: Halevy et al. 2015 & 2018-CY: Kleitou et al. 2019 \\
\hline $\mathrm{MOL}$ & Isognomon legumen (Gmelin, 1791) & 2015-IL: Mienis et al. 2016 & $\begin{array}{l}\text { 2016-GR: Micali et al. } 2017 \text { / 2017-TR: Ovalis \& Zenetos in } \\
\text { Stamouli et al. } 2017 \text { /2017-IT: Scuderi and Viola } 2019\end{array}$ \\
\hline $\mathrm{MOL}$ & Plocamopherus tilesii Bergh, 1877 & 2009-TR: Yokeş et al. 2012 & TR: B. Yokeş pers commun \\
\hline $\mathrm{PHY}$ & $\begin{array}{l}\text { Chaetoceros bacteriastroides } \\
\text { G.H.H.Karsten, } 1907\end{array}$ & 2002-IT: Sarno and Zingone 2008 & 2010-HR: Čalić et al., 2017 \\
\hline PLAT & $\begin{array}{l}\text { Neoallolepidapedon hawaiiense } \\
\text { Yamaguti, } 1965\end{array}$ & 2006-TN: Merella et al. 2007 & LY: Salem 2017 \\
\hline
\end{tabular}

Taxonomic group abbreviations: PHY Phytoplankton, BRY Bryozoa, CNI Cnidaria, CRU Crustacea, FISH Fishes, MOL Mollusca, PLAT Platyelminthes. Country codes follow the internationally accepted two-letter codes for countries (https://www.worldatlas.com/aatlas/ctycodes.htm)

Libya (Osca et al. 2020), in both cases supported by DNA sequencing.

A worrying development is the widespread establishment of Oithona davisae Ferrari and Orsi 1984, as already anticipated by Karachle et al. (2017). This cyclopoid copepod, previously only reported from Spain within the Mediterranean (Saiz et al. 2003), has now been recorded with considerable populations from the Aegean Sea (Dragičević et al. 2019; Terbiylk Kurt and Beşiktepe 2019), the port of Venice (Zagami et al. 2018) and southern Italy (Vidjak et al. 2019), presumably carried with ballast waters and aquaculture transports. It displays an invasive character in San Francisco Bay (Ferrari and Orsi 1984) and the Black Sea (Seregin and Popova 2019) by competitive exclusion of native copepod species, while it is suspected that it can affect pelagic food webs through increased consumption of flagellates and interference with larval fish feeding (Karachle et al. 2017). The Indo-West Pacific rock shrimp Sicyonia lancifer (Olivier, 1811) is now confirmed as established in Israel, with multiple specimens having been collected by trawl fishermen in 2019 (Galil \& Lubinevsky in Stern et al. 2019). The species was already present in a number of locations in Turkey and one in Israel by 2016 (Gönülal et al. 2016; Patania and Mutlu 2016) but due to the sporadic specimens and novelty of the invasion, it was not considered established in the Zenetos et al. (2017) update.

For the nudibranch Plocamopherus tilesii Bergh, 1877, local establishment in Turkish waters was confirmed by 
Yokeş (pers. comm.) who has caught 12 specimens since the first record in 2009, during seasonal trawl surveys in Mersin Bay. Another notable species with multiple new occurrences in the past 3 years is the Lessepsian fish Pomacanthus imperator (Bloch, 1787), which has spread along the Levantine coast from Israel as far as southern Turkey (Gürlek et al. 2019). While it was initially hypothesized that the species' introduction may have also resulted from an aquarium escape (Golani et al. 2010), recent genetic evidence indicates introduction through the Suez Canal as the most plausible pathway (Stern et al. 2019).

As much as the spread pattern of $P$. imperator is a typical example of natural dispersal, the case of Watersipora arcuata Banta, 1969 is exactly the opposite. A relatively recent introduction, this fouling bryozoan was only known from one location in the Ligurian Sea, Italy (Ferrario et al. 2015) up to the compilation by Zenetos et al. (2017). In a matter of 2-3 years the species was discovered in Spain, Malta, Sicily, Turkey (Ulman et al. 2017) and the Tyrrhenian Sea (Ferrario et al. 2017), always in marinas for recreational craft. Another species most likely spreading via hull fouling is the colonial scleractinian coral Oulastrea crispata (Lamarck, 1816). The species, which was only recorded once in Corsica in 2012 (Hoeksema and Ocaña 2014), has now been found in two additional locations in Spain (Mariani et al. 2018) and is considered established in the western Mediterranean.

The parasite Neoallolepidapedon hawaiiense Yamaguti, 1965, which was thus far recorded only once in Tunisia in 2007 from Fistularia commersonii Rüppell, 1838 (Merella et al. 2007), has also changed its establishment success in the Mediterranean. The species has now been also reported from Libya, in the same host, by Salem (2017), and is considered established in the central Mediterranean. Regarding the establishment status of parasites with complex life cycles, one could argue that establishment success can only be affirmed if the intermediate hosts have been found carrying the parasites as well; otherwise a plausible hypothesis would be that the findings belong to residual infections that took place before the definitive host's migration (Merella et al. 2010). Besides the fact that this is an overly strict criterion, given the scarcity of distributional information on many of these parasites, the alternative assumption would be that each alien parasite record represents a new introduction event, which does not seem plausible either. Thus, while high uncertainty in their establishment success is acknowledged, alien parasites follow the same criteria for establishment outlined in the methods section and in Zenetos et al. (2017) and Zenetos et al. (2008).

Lastly for this group, a small number of species which were considered established until Zenetos et al. (2017) have now been re-classified as casual, due to the absence of any further records.
These are: Papilloculiceps longiceps (Cuvier, 1829), an Indian ocean fish species reported only from Israel (Golani and Ben 1990); Parvocalanus latus Andronov, 1972, a species native in the Indian Ocean reported only from S. Turkey (Uysal et al. 2002); Terapon theraps $\mathrm{Cu}$ vier, 1829, an Indo-Pacific species with only two records of single specimens in Slovenia (Lipej et al. 2008) and Greece (Minos et al. 2012) and whose presence cannot be attributed to any pathway of introduction.

\section{Species that have expanded their distribution into new MSFD regions}

A total of 36 species have expanded their distribution into new MSFD regions, of which 21 are already established in the new locations (Table 4).

The main pathways implicated in their spread are natural dispersal from neighbouring areas (unaided pathway) and hull fouling $(\mathrm{n}=13)$, while ship-mediated pathways as a whole are considered responsible for the spreading of 24 species. The number of hull-fouling species records has undoubtedly been augmented since Zenetos et al. (2017) by the extensive study of Ulman et al. (2017), who sampled a large number of recreational marinas in the Mediterranean, targeting specifically alien species. It is also worth noting that the majority of large, conspicuous species, i.e. fishes and molluscs that disperse naturally $(\mathrm{n}=11)$, were recorded by citizen scientists and communicated to the authors through increasingly expanding initiatives and networks with national experts (e.g. expansion records of Pterois miles (Bennett, 1828 and, Etrumeus golanii in Table 4, but also Pomacanthus imperator and Charybdis feriata (Linnaeus, 1758) in Table 3).

The Central Mediterranean received the highest number of expanding species $(\mathrm{n}=19)$, which is not surprising, given its central position in the region, which is critical both for natural dispersal but also for its busy shipping routes and transshipment hubs (Crocetta et al. 2015; Deidun et al. 2018). The Western Mediterranean was the recipient of only 7 expanding species, primarily through shipping vectors, with the exception of two Lessepsian fishes and one fish parasite. Etrumeus golanii, which has already attained commercial significance in the Eastern Mediterranean (DiBattista et al. 2012), has recently spread through the central basin all the way to the Alboran Sea (Tamsouri et al. 2019). Pteragogus trispilus, another Lessepsian immigrant, appears to be pushing the lower limits of its thermal envelope both in the Aegean (Yapici et al. 2015) and along the African coast, having been observed in the Gulf of Tunis in 2016 (Hamed et al. 2018).

Ten species expanded their Mediterranean distribution into the Adriatic Sea, most of them already widespread in two or three MSFD sectors of the basin. Of 
Table 4 Species expanding their distribution into new MSFD areas

\begin{tabular}{|c|c|c|c|c|c|c|}
\hline $\begin{array}{l}\text { Higher } \\
\text { taxon }\end{array}$ & Species & From & To & status & pathway & Expansion record(s) \\
\hline ASC & $\begin{array}{l}\text { Perophora multiclathrata } \\
\text { (Sluiter, 1904) }\end{array}$ & WMED & CMED & unk & T-S (fouling) & IT: Lezzi et al., 2018 \\
\hline $\mathrm{PHY}$ & $\begin{array}{l}\text { Chaetoceros bacteriastroides } \\
\text { G.H.H.Karsten, } 1907\end{array}$ & WMED & ADRIA & est & T-S (ballast) & HR: Čalić, M., et al., 2018 \\
\hline BRY & $\begin{array}{l}\text { Parasmittina egyptiaca } \\
\text { (Waters, 1909) }\end{array}$ & EMED & CMED & unk & T-S (fouling) & IT: Ulman et al., 2017 \\
\hline BRY & Watersipora arcuata Banta, 1969 & WMED & $\begin{array}{l}\text { CMED, } \\
\text { EMED }\end{array}$ & est & T-S (fouling) & ES, IT, MT, TR: Ulman et al., 2017 \\
\hline $\mathrm{CHL}$ & $\begin{array}{l}\text { Ulva ohnoi M.Hiraoka \& } \\
\text { S.Shimada, } 2004\end{array}$ & WMED & $\begin{array}{l}\text { CMED, } \\
\text { EMED }\end{array}$ & est & T-S (fouling) & IL: Krupnik et al., 2018 / TN: Miladi et al., 2018 \\
\hline CRU & $\begin{array}{l}\text { Paracaprella pusilla Mayer, } \\
1890\end{array}$ & $\begin{array}{l}\text { EMED, } \\
\text { WMED }\end{array}$ & CMED & est & T-S (fouling) & TN: Fersi et al., 2018 \\
\hline CRU & $\begin{array}{l}\text { Stenothoe georgiana Bynum } \\
\& \text { Fox, } 1977\end{array}$ & WMED & CMED & est & T-S (fouling) & IT: Ulman et al., 2017 \\
\hline CRU & $\begin{array}{l}\text { Oithona davisae Ferrari F.D. } \\
\text { \& Orsi, } 1984\end{array}$ & WMED & $\begin{array}{l}\text { EMED, } \\
\text { CMED, } \\
\text { ADRIA }\end{array}$ & est & T-S (ballast) & $\begin{array}{l}\text { GR: Dragičević et al., 2019; TR: Terbıyık Kurt \& Beşiktepe, } \\
2019 \text { / IT: Zagami et al., } 2018 \text { / IT: Vidjak et al., } 2019\end{array}$ \\
\hline CRU & Dyspanopeus sayi (Smith, 1869) & CMED & EMED & cas & T-S (ballast)/CON & GR: Ulman et al., 2017 \\
\hline CRU & $\begin{array}{l}\text { Anilocra pilchardi Bariche \& } \\
\text { Trilles, } 2006\end{array}$ & $\begin{array}{l}\text { EMED, } \\
\text { CMED }\end{array}$ & WMED & unk & UNA & TN: Ounifi Ben Amor et al., 2017 \\
\hline CRU & $\begin{array}{l}\text { laniropsis serricaudis Gurjanova, } \\
1936\end{array}$ & ADRIA & WMED & est & T-S (fouling) & IT: Ferrario et al., 2017 / FR: Ulman et al., 2017 \\
\hline FISH & $\begin{array}{l}\text { Bregmaceros nectabanus } \\
\text { Whitley } 1941\end{array}$ & EMED & CMED & est & UNA & GR: Ketsilis-Rinis \& Dimitriou in Chartosia et al., 2018 \\
\hline $\mathrm{FISH}$ & $\begin{array}{l}\text { Etrumeus golanii Di Battista, } \\
\text { Randall \& Bowen, } 2012\end{array}$ & $\begin{array}{l}\text { EMED, } \\
\text { CMED }\end{array}$ & WMED & est & UNA & $\begin{array}{l}\text { DZ: Kassar \& Hemida in Stamouli et al., } 2017 \text { / TN: } \\
\text { Rafrafi-Nouira et al., } 2017 \text { / MA: Tamsouri et al., } 2019\end{array}$ \\
\hline FISH & $\begin{array}{l}\text { Parupeneus forsskali (Fourmanoir } \\
\text { \& Guézé, 1976) }\end{array}$ & EMED & CMED & est & UNA & TN: Capapé et al., 2018b \\
\hline FISH & $\begin{array}{l}\text { Pteragogus trispilus Randall, } \\
2013\end{array}$ & $\begin{array}{l}\text { EMED, } \\
\text { CMED }\end{array}$ & WMED & cas & UNA & TN: Hamed et al., 2018 \\
\hline FISH & Pterois miles (Bennett, 1828) & $\begin{array}{l}\text { EMED, } \\
\text { WMED }\end{array}$ & CMED & est & UNA & $\begin{array}{l}\text { IT: Azzurro et al., } 2017 \text { / GR: Mitsou \& Maximiadi } \\
\text { in Yokeş et al., } 2018 \text { / LY: Al Mabruk \& Rizgalla, } 2019\end{array}$ \\
\hline $\mathrm{FISH}$ & $\begin{array}{l}\text { Sciaenops ocellatus } \\
\text { (Linnaeus, 1766) }\end{array}$ & EMED & CMED & est & UNA & IT: Langeneck et al., 2017 \\
\hline $\mathrm{FISH}$ & $\begin{array}{l}\text { Synchiropus sechellensis } \\
\text { Regan, } 1908\end{array}$ & GR: EMED & CMED & unk & UNA & GR: Teneketzis \& Christidis in Yokeş et al., 2018 \\
\hline $\mathrm{MOL}$ & $\begin{array}{l}\text { Dendostrea cf folium } \\
\text { (Linnaeus, 1758) }\end{array}$ & EMED & ADRIA & est & T-S (fouling) & AL: Xharahi et al. in Gerovasileiou et al., 2017 \\
\hline $\mathrm{MOL}$ & $\begin{array}{l}\text { Fulvia fragilis } \\
\text { (Forsskål in Niebuhr, 1775) }\end{array}$ & $\begin{array}{l}\text { EMED, } \\
\text { CMED, } \\
\text { WMED }\end{array}$ & ADRIA & est & T-S/UNA & $\begin{array}{l}\text { AL: Xharahi et al. in Gerovasileiou et al., } 2017 \text { / ME: } \\
\text { Gvozdenović et al., } 2019\end{array}$ \\
\hline $\mathrm{MOL}$ & $\begin{array}{l}\text { Malleus regula (Forsskål in } \\
\text { Niebuhr, 1775) }\end{array}$ & EMED & CMED & est & T-S (fouling) & IT: Prato \& Rubino in Kousteni et al., 2019 \\
\hline $\mathrm{MOL}$ & $\begin{array}{l}\text { Sepioteuthis lessoniana Férussac } \\
\text { [in Lesson], } 1831\end{array}$ & $\begin{array}{l}\text { EMED, } \\
\text { CMED }\end{array}$ & ADRIA & est & UNA & ME: Dragičević et al. in Stern et al., 2019 \\
\hline $\mathrm{MOL}$ & Biuve fulvipunctata (Baba, 1938) & $\begin{array}{l}\text { EMED, } \\
\text { CMED, } \\
\text { WMED }\end{array}$ & ADRIA & est & UNA & HR: Petani \& Crocetta in Kousteni et al., 2019 \\
\hline $\mathrm{MOL}$ & $\begin{array}{l}\text { Conomurex persicus } \\
\text { (Swainson, 1821) }\end{array}$ & $\begin{array}{l}\text { EMED, } \\
\text { CMED }\end{array}$ & ADRIA & unk & T-S/UNA & AL: Xharahi et al. in Gerovasileiou et al., 2017 \\
\hline $\mathrm{MOL}$ & $\begin{array}{l}\text { Diodora ruppellii } \\
\text { (G. B. Sowerby I, 1835) }\end{array}$ & $\begin{array}{l}\text { EMED, } \\
\text { WMED }\end{array}$ & CMED & cas? & $\begin{array}{l}\text { T-S (fouling)/ } \\
\text { UNA }\end{array}$ & LY: Rizgalla et al., 2019 \\
\hline
\end{tabular}


Table 4 Species expanding their distribution into new MSFD areas (Continued)

\begin{tabular}{|c|c|c|c|c|c|c|}
\hline $\begin{array}{l}\text { Higher } \\
\text { taxon }\end{array}$ & Species & From & To & status & pathway & Expansion record(s) \\
\hline $\mathrm{MOL}$ & $\begin{array}{l}\text { Godiva quadricolor } \\
\text { (Barnard, 1927) }\end{array}$ & $\begin{array}{l}\text { WMED, } \\
\text { ADRIA }\end{array}$ & CMED & est & $\mathrm{T}-\mathrm{S} / \mathrm{CON}$ & IT: Furfaro et al., 2018 \\
\hline $\mathrm{MOL}$ & $\begin{array}{l}\text { Haminoea cyanomarginata } \\
\text { Heller \& Thompson, } 1983\end{array}$ & $\begin{array}{l}\text { EMED, } \\
\text { CMED, } \\
\text { WMED }\end{array}$ & ADRIA & unk & T-S/UNA & HR: Dragicevic et al. in Chartosia et al., 2018 \\
\hline PLAT & $\begin{array}{l}\text { Allolepidapedon fistulariae } \\
\text { Yamaguti, } 1940\end{array}$ & $\begin{array}{l}\text { EMED, } \\
\text { WMED }\end{array}$ & CMED & unk & UNA & LY: Salem, 2017 \\
\hline PLAT & $\begin{array}{l}\text { Glyphidohaptor plectocirra } \\
\text { (Paperna, 1972) Kritsky, } \\
\text { Galli \& Yang, } 2007\end{array}$ & EMED & CMED & unk & UNA & LY: Abdelnor et al., 2019 \\
\hline PLAT & $\begin{array}{l}\text { Maritigrella fuscopunctata } \\
\text { (Prudhoe, 1978) }\end{array}$ & CMED & EMED & unk & T-S/UNA & IL: Velasquez et al., 2018 \\
\hline POL & $\begin{array}{l}\text { Chaetozone corona Berkeley } \\
\text { \& Berkeley, } 1941\end{array}$ & $\begin{array}{l}\text { EMED, } \\
\text { CMED }\end{array}$ & $\begin{array}{l}\text { ADRIA, } \\
\text { WMED }\end{array}$ & est & T-S (ballast) & $\begin{array}{l}\text { IT (ADRIA): Munari et al., 2017; Grossi et al., } 2017 \text { / IT } \\
\text { (WMED): Munari et al., } 2017\end{array}$ \\
\hline POL & $\begin{array}{l}\text { Desdemona ornata } \\
\text { Banse, } 1957\end{array}$ & $\begin{array}{l}\text { EMED, } \\
\text { ADRIA, } \\
\text { WMED }\end{array}$ & CMED & unk & $\mathrm{T}-\mathrm{S} / \mathrm{CON}$ & TN: Boudaya et al., 2019 \\
\hline POL & $\begin{array}{l}\text { Dorvillea similis } \\
\text { (Crossland, 1924) }\end{array}$ & EMED & WMED & est & $\begin{array}{l}\text { T-S (fouling)/ } \\
\text { UNA }\end{array}$ & IT: Langeneck \& Tempesti in Dragicevic et al., 2019 \\
\hline POL & $\begin{array}{l}\text { Hydroides brachyacantha } \\
\text { Rioja, } 1941\end{array}$ & EMED & WMED & unk & T-S (fouling) & ES: Ulman et al., 2017 \\
\hline POL & Palola valida (Gravier, 1900) & EMED & ADRIA & unk & T-S (fouling) & ME: Spagnolo et al., 2019 \\
\hline $\mathrm{RHO}$ & $\begin{array}{l}\text { Chondria curvilineata F.S.Collins } \\
\text { \& Hervey, } 1917\end{array}$ & $\begin{array}{l}\text { EMED, } \\
\text { WMED }\end{array}$ & CMED & est & T-S & IT: Alongi in Gerovasileiou et al., 2017 \\
\hline
\end{tabular}

The pathway column refers to the most likely pathway of secondary spread. Taxonomic group and Pathway abbreviations as in Table 2

these, Sepiotheuthis lessoniana and Biuve fluvipunctata seem to be spreading unaided from the neighbouring Ionian Sea (Stern et al. 2019; Kousteni et al. 2019 respectively), while for the other species shipping vectors are implicated in their expansion. The Eastern Mediterranean, most commonly the starting point for the spread of naturally dispersing Lessepsian migrants, received 5 species, all most likely associated with shipmediated pathways. The Indo-Pacific flatworm Maritigrella fuscopunctata, which was first observed in Malta (Crocetta et al. 2015) may constitute an exception, as its presence was already suspected along the Levantine coast and was later confirmed in Israel (Velasquez et al. 2018), such that entrance through the Suez Canal cannot be excluded.

\section{OTHER changes}

Nomenclature has changed for 20 species, while there were year and/or country changes of first records in 13 cases (Additional file 2). These include: Plagusia squamosa (Herbst, 1790), Prionospio pulchra Imajima 1990, Aurelia solida Browne, 1905; Ulva ohnoi M. Hiraoka \& S. Shimada, Magallana gigas (Thunberg, 1793), Hypnea spinella (C.Agardh) Kützing, Leodice antennata Savigny in Lamarck, 1818, Siganus luridus (Rüppell, 1829) and Upeneus moluccensis (Bleeker, 1855). Noteworthy are the records of Plagusia squamosa (Herbst, 1790) since 1903 in Italy (see Servello et al. 2019) and Aurelia solida Browne, 1905 in Tunisia since at least 1994 (Gueroun et al. 2020).

\section{General discussion}

To summarise, the current update adds 70 species to the established alien species inventory of the Mediterranean Sea (Additional file 1). Besides the 25 missing records, there are 23 newly introduced species between 20172019 which are already established. At the same time period, 22 species that were previously considered casual, based on 1-2 location records and/or single specimens, are now well-established, as anticipated by Zenetos et al. (2017), some of them with an impressive spatial distribution (see Oithona davisae, Isognomon legumen, Pomacanthus imperator and Watersipora arcuata in Table 3). Similarly, a considerable number of species have expanded their distribution into new MSFD areas, with the Central Mediterranean and the Adriatic Sea the main recipients of this expansion. A number of reasons can be invoked for this apparent increase in the rate of spread and establishment of Mediterranean alien species. Two of them are related to the rate of discovery of new presence records, driven by intensified research efforts on marine NIS. EU regulations, such as the Marine Strategy Framework Directive (EC (European Commission) 2008), 
the Biodiversity Strategy (EC (European Commission) 2011; EC (European Commission) 2014), the IAS Regulation (EU Regulation 2014), the Ballast Water Management Convention (IMO (International Maritime Organization) 2004; IMO (International Maritime Organization) 2017), have resulted in a large demand in relevant data production and reporting and are the driving force behind dedicated research projects and national monitoring schemes for NIS. Furthermore, the increased appreciation of stakeholder involvement (Azzurro et al. 2019) and the burst in citizen science initiatives and networks (e.g. Zenetos et al. 2013; Crocetta et al. 2017; Giovos et al. 2019) has undoubtedly improved the spatial scale and temporal resolution of alien species detection, monitoring and surveillance.

The above notwithstanding, climate change is also expected to have played a role in this accelerated rate of alien species expansion. Warming of the Mediterranean Sea surface waters between 1985-2006 has been estimated at $0.04{ }^{\circ} \mathrm{C} /$ year, leading to an overall SST increase of approximately $1^{\circ} \mathrm{C}$ for the eastern basin, with the Aegean Sea and the Adriatic among the hotspots of this warming trend (Nykjaer 2009). For marine species, geographic ranges conform closely to their thermal limits (Sunday et al. 2012; Payne et al. 2016), which in turn show higher plasticity at their lower end (Stuart-Smith et al. 2017). Expansion records of Indo-Pacific species discussed in previous sections indicate that a number of species are likely already favoured by increased temperatures, exhibiting their northernmost records in the Mediterranean (e.g. Sepioteuthis lessoniana Férussac [in Lesson], 1831, Biuve fulvipunctata (Baba, 1938), Haminoea cyanomarginata Heller \& Thompson, 1983) or pushing their way into cooler western Mediterranean waters (e.g. Etrumeus golanii).

Attention needs to be paid to the fact that the observed rate of new introductions does not appear to be related to the enlargement of the Suez Canal, verifying the findings of Zenetos $(2017,2019)$. When all potential pathways are considered for the new species introduced between 2017-2019, it is only 4 species per year that seem to enter the Mediterranean through the Suez Canal, a number much lower than the 7 species per year, reported by Zenetos et al. (2017) for the period 20152017. An appreciable number of alien species were introduced to Mediterranean waters via shipping pathways (7 in total), predominantly zoobenthic and planktonic species, as well as benthic plants. Aquaria releases have also contributed 7 species in total to the Mediterranean xenodiversity, all but one demersal fish with, as of yet, only casual records since 2017. A characteristic example is the high-valued aquarium species Abudefduf sexfasciatus (Lacepède, 1801), native to the Red Sea, which was however observed for the first time in Greek waters, too far away from the Suez Canal (Giovos et al. 2018). Chrysiptera hemicyanea (Weber, 1913) on the other hand, a typical coral-reef dweller, is not found in the Red Sea and is almost certainly released from an aquarium into Maltese waters (Deidun et al. 2018). It remains to be seen whether some of these species will be confirmed as aquarium releases or will be proven Lessepsian migrants by additional records and/or genetic evidence, as was the case for Acanthurus sohal (Forsskål, 1775) (Bariche et al. 2019) and Pomacanthus imperator (Bloch, 1787) (Stern et al. 2019).

In agreement with Zenetos et al. (2017), we consider this a "provisional" list, presenting the changes in Mediterranean marine alien species since the end of 2016. We acknowledge that even the current update may contain errors, as species invasions are dynamic phenomena, where new information continually comes to light, whether from new observations or from re-examination of older material, changes in nomenclature and phylogenetic studies. Finally, we re-affirm the critical role of international collaboration and consultation with local and taxonomic experts in keeping these important policy tools as accurate and up-to-date as possible in order to provide well-informed management and policy advice.

\section{Supplementary information}

Supplementary information accompanies this paper at https://doi.org/10. 1186/s41200-020-00191-4.

\section{Additional file 1.}

Additional file 2.

\section{Acknowledgements}

We would like to thank the following colleaques for advise provided on the establishment success of selected species/taxa: Dani Golani (Papilloculiceps longiceps, Coryogalops ocheticus and Terapon theraps), Nir Stern (Papilloculiceps longiceps), Dori Edelist, Gil Rilov, Shevy Rothman (Papilloculiceps longiceps, Abudefduf sexfasciatus), Marcello Kovacic (Coryogalops ocheticus), Melih Ertan Çinar (Spiophanes algidus), Tuba Terbiyk Kurt (zooplankton), Liron Goren (Iphinoe muricata), Razy Hoffman (Codium pulvinatum), Marc Verlaque (2 macroalgae), Carla Morri (Diphasia digitalis), Fabio Crocetta (molluscs), Serge Gofas (Pseudochama corbierei), Ghazi Bitar (Diphasia digitalis), Baki Yokes (Plocamopherus tilesii), Paolo Merella (Lessepsian parasites), Xavier Turon (ascidians) and the anonymous reviewers whose constructive criticism has improved our manuscript. Finally, we would like to extend our sincere gratitude and appreciation to the editor, John Bishop, whose dedicated effort and commitment to detail substantially contributed to the integrity of this work.

\section{Authors' contributions}

AZ conceived the study, collected the literature, maintains the HCMR offline database and compiled the tables. MG contributed to the data collection and proofing and table collation. Both authors contributed equally to the drafting of the manuscript and approved the final manuscript. 


\section{Author details}

${ }^{1}$ Hellenic Centre for Marine Research, Attiki, Greece. ${ }^{2}$ ÜEE LLC, Marine

Ecology Division, Teknopark Izmir A1/49, Urla, Izmir, Turkey.

Received: 13 February 2020 Accepted: 1 July 2020

Published online: 31 August 2020

\section{References}

Abd El-Rahman NS. The immigration progress of planktonic Copepoda across the Suez Canal, Egypt. Egypt J Aquat Biol Fish. 2005;9(3):59-82.

Abdel-Latif HMR. Cymothoid parasite, Nerocila orbigni inflicts great losses on Tilapia zilli in Lake Qarun at El-Fayoum Province. Int J Innov Stud Aquatic Biol Fisheries (IJISABF). 2016;2(3):1-9.

Abdelnor Z, Niver L, Bauselw W, Al-Sharief R, Ben Zegalam S, Shakman E. Parasite fauna of the herbivorous fish Siganus luridus (Ruppell, 1829), Siganus rivulatus (Forsskal, 1775) and Sarpa salpa (Linnaeus, 1758) in the western coast of Libya. AntalyaTurkey, 17-18 January 2019: 1st Mediterranean Symposium on the Non-Indigenous Species; 2019. p. 91

Abdelsalam. First record of exotic Lysmatid shrimp Lysmata vittata (Stimpson, 1860) (Decapoda: Caridea: Lysmatidae) from the Egyptian Mediterranean coast. Mediterr Mar Sci. 2018;19(1):124-31 https://doi.org/10.12681/mms. 15591.

Abdelsalam KM, Taylor PD, Dorgham MM. A new species of Calyptotheca (Bryozoa: Cheilostomata) from Alexandria, Egypt, southeastern Mediterranean. Zootaxa. 2017;4276(4):582-90.

Abelló P, Hispano C. The capture of the indo-Pacific crab Charybdis feriate (Linnaeus, 1758) (Brachyura: Portunidae) in the Mediterranean Sea. Aquat Invasions. 2006; 1 (1):13-6.

Açik S, Murina GW, Çinar ME, Ergen Z. Sipunculans from the coast of northern Cyprus. Zootaxa. 2005;1077:1-23.

Al Mabruk SA, Rizgalla J. First record of lionfish (Scorpaenidae: Pterois) from Libyan waters. J Black Sea/Medit Environ. 2019;25(1):108-14.

Alshawy F, Ibrahim A, Hussein C, Lahlah M. First record of the blacktip cardinalfish Apogon atradorsatus Heller \& Snodgrass, 1903 from Syrian marine waters (eastern Mediterranean). Int J Adv Res Sci Eng Technol. 2019b;6:5.

Alshawy F, Ibrahim A, Hussein C, Lahlah M. First record of the flat needlefish Ablennes hians (Valenciennes, 1846) from Syrian marine waters (eastern Mediterranean). Mar Biodivers Rec. 2019a;12(1):15.

Angelidis A, Polyzoulis G. New distributional records of four indo-Pacific species from Astypalaia Island, South Aegean Sea. Greece Xenophora Taxonomy. 2018:21:3-10

Armeli MS. Biodiversity of the lagoon of Venice and of the venetian northern Adriatic coast. Boll Mus St Nat Venezia. 2013;64:141-7.

Armon RH, Zenetos A. Invasive alien species and their indicators. In: Environmental indicators. Dordrecht: Springer; 2015. p. 147-73.

Aslan H, Ovalis P. On the discovery of Crithe cossinea T. Cossignani, 1997, a new marine alien species for the Mediterranean Sea, with additions and remarks on 15 unreported molluscan species from Turkey coast. Cah Biol Mar. 2017; 58(2):173-80

Avian M, Ramšak A, Tirelli V, D'Ambra I, Malej A. Redescription of Pelagia benovici into a new jellyfish genus, Mawia, gen. Nov., and its phylogenetic position within Pelagiidae (Cnidaria: Scyphozoa: Semaeostomeae). Invertebr Syst. 2016;30(6):523-46 https://doi.org/10.1071/IS16010.

Aydin M, Gurlek M, Samyn Y, Erguden D, Turan C. First record of a Lessepsian migrant: the sea cucumber Holothuria (Theelothuria) hamata Pearson, 1913. Zootaxa. 2019;4551(1):94-100 https://doi.org/10.11646/zootaxa.4551.1.7.

Azzurro E, Bolognini L, Dragičević B, Drakulović D, Dulčić J, Fanelli E, et al. Detecting the occurrence of indigenous and non-indigenous megafauna through fishermen knowledge: a complementary tool to coastal and port surveys. Mar Pollut Bull. 2019;147:229-36.

Azzurro E, Stancanelli B, Di Martino V, Bariche M. Range expansion of the common lionfish Pterois miles (Bennett, 1828) in the Mediterranean Sea: an unwanted new guest for Italian waters. Biolnvasions Rec. 2017;6(2):95-8.

Badreddine A, Bitar G. First record of Heteropriacanthus cruentatus (Lacepède, 1801) (Chordata: Priacanthidae) in the Mediterranean Sea from the Lebanese waters. J Black Sea/Mediter Envir. 2019;25(2):178-81.

Barash A, Danin Z. The indo-Pacific species of Mollusca in the Mediterranean and notes on a collection from the Suez Canal. Isr J Zool. 1972;21(3-4):301-74.

Bariche M. First record of the cube boxfish Ostracion cubicus (Ostraciidae) and additional records of Champsodon vorax (Champsodontidae) from the Mediterranean. Aqua. 2011;17(4):181-4.
Bariche M, Constantinou C, Sayar N. First confirmed record of the white-spotted puffer Arothron hispidus (Linnaeus, 1758) in the Mediterranean Sea. Biolnvasions Rec. 2018;7(4):433-6.

Bariche M, Fricke R. Dipterygonotus balteatus (Valenciennes, 1830) (Teleostei: Caesionidae), a new alien fish in the Mediterranean Sea. Biolnvasions Rec. 2018;7(1):79-82.

Bariche M, Sayar N, Balistreri P. Records of two non-indigenous fish species Synanceia verrucosa Bloch and Schneider, 1801 and Acanthurus sohal (Forsskål, 1775) from the Gaza strip (eastern Mediterranean Sea). Biolnvasions Rec. 2019;8:699-705.

Băsescu M. Les Mysidacés des eaux méditerranéennes de la France (spécialement de Banyuls) et des eaux de Monaco. Bull Inst Océanogr Monaco. 1941;795:1-46.

Bayha KM, Collins AG, Gaffney PM. Multigene phylogeny of the scyphozoan jellyfish family Pelagiidae reveals that the common US Atlantic sea nettle comprises two distinct species (Chrysaora quinquecirrha and C. chesapeakei). PeerJ. 2017;5:e3863.

Bos AR, Ogwang J. Caesio varilineata carpenter, 1987 (Osteichthyes: Caesionidae) a new alien fish in the southeastern Mediterranean Sea. Biolnvasions Rec. 2018;7(4):441-5.

Boudaya L, Mosbahi N, Dauvin JC, Neifar L. Structure of the benthic macrofauna of an anthropogenic influenced area: Skhira Bay (gulf of Gabès, Central Mediterranean Sea). Environ Sci Pollut Res Int. 2019;26(13):13522-38.

Boussellaa W, Neifar L, Goedknegt MA, Thieltges DW. Lessepsian migration and parasitism: richness, prevalence and intensity of parasites in the invasive fish Sphyraena chrysotaenia compared to its native congener Sphyraena sphyraena in Tunisian coastal waters. PeerJ. 2018;6:e5558.

Bradford-Grieve JM. Copepoda sub-order: Calanoida, family: Acartiidae, genera: Acartia, Paracartia, Pteriacartia. In: To replace fiches d'identification du plancton no. 12. ICES identification leaflets for plankton = fiches d'identification du plancton, 181. Copenhagen: ICES; 1999. p. 19.

Čalić M, Ljubimir S, Bosak S, Car A. First records of two planktonic indo-Pacific diatoms: Chaetoceros bacteriastroides and C. pseudosymmetricus in the Adriatic Sea. Oceanologia. 2018;60(1):101-5.

Capapé C, Ali M, Ali A, Esmail A. Second Mediterranean record of emperor angelfish, Pomacanthus imperator (Osteichthyes: Pomacanthidae), and first record from the Syrian coast. Cah Biol Mar. 2018a:59:395-7.

Capapé C, Zaouali J, Ounifi-Ben Amor H, Ben Amor MM. First record of Red Sea goatfish Parupeneus forsskali (Osteichthyes: Mullidae) from Tunisian waters (Central Mediterranean Sea). ANNALES · Ser Hist Nat. 2018b;28(2):107-10.

Castelló J, Bitar G, Zibrowius H. Isopoda (crustacea) from the Levantine Sea with comments on the biogeography of mediterranean isopods. Mediterr Mar Sci. 2020;19:308-39 https://doi.org/10.12681/mms.20329.

CBD (Convention on Biological Diversity). Conference of the parties decision X/2: strategic plan for biodiversity 2011-2020. Montreal: The Secretariat of the Convention on Biological Diversity; 2011.

CBD (Convention on Biological Diversity). Pathways of introduction of invasive species, their prioritization and management. UNEP/CBD/SBSTTA/18/9/add.1. Montréal: Secretariat of the Convention on Biological Diversity; 2014. p. 18.

Cervera JL, Calado G, Gavaia C, Malaquias MA, Templado J, Ballesteros MB, et al. An annotated and updated checklist of the ophsthobranchs (Mollusca: Gastropoda) from Spain and Portugal (including islands and archipelagos). Bol Inst Esp Oceanogr. 2004;20(1-4):1-122.

Cesari P. I molluschi della laguna di Venezia. Arsenale Ed. 1994:189.

Chartosia N, Anastasiadis D, Bazairi H, Crocetta F, Deidun A, Despalatović M, et al. New Mediterranean biodiversity records (July 2018). Mediterr Mar Sci. 2018; 19:398-415 https://doi.org/10.12681/mms.18099.

Cifftçi O, Karahan A, A Korek Y, Kideys AE. First record of the buccaneer anchovy Encrasicholina punctifer (fowler, 1938)(Clupeiformes; Engraulidae) in the Mediterranean Sea, confirmed through DNA barcoding. J Appl Ichthyol. 2017;33(3):520-3.

Colmenero A, Barria C, Abello P. Has the portunid crab Chanybdis feriata already established a population in the Mediterranean Sea? Cah Biol Mar. 2019;60(2):201-4.

Corsini-Foka M, Zenetos A, Crocetta F, Çinar ME, Koçak F, Golani D, et al. Inventory of alien and cryptogenic species of the Dodecanese (Aegean Sea, Greece): collaboration through COST action training school. Manag Biol Invasion. 2015;6:351-66 https://doi.org/10.3391/mbi.2015.6.4.04.

Crocetta F, Agius D, Balistreri P, Bariche M, Bayhan YK, Çakir M, et al. New Mediterranean biodiversity records (October 2015). Mediterr Mar Sci. 2015;16(3):682-702.

Crocetta F, Gofas S, Salas C, Tringali LP, Zenetos A. Local ecological knowledge versus published literature: a review of non-indigenous Mollusca in Greek marine waters. Aquat Invasions. 2017;12(4):415-34. 
Deidun A, Castriota L, Falautano M, Maggio T. Yet another angelfish species for the Mediterranean - the first record of Holacanthus africanus Cadenat, 1951 from Maltese waters, Central Mediterranean. Bioinvasions Rec. 2017:6(4):373-6.

Deidun A, De Castro D, Bariche M. First record of the azure demoiselle, Chrysiptera hemicyanea (Actinopterygii: Perciformes: Pomacentridae), in the Mediterranean Sea. Acta Ichthyol Piscat. 2018;48(1):87-91.

Demetropoulos A. Marine molluscs of Cyprus. Part B Fish Bull. 1971;3(34):4.

Di Capua I, Boxshall GA. Records of Oncaeidae (Copepoda) from the Gulf of Naples, with new records of three species of Triconia. J Mar Biol Assoc UK. 2008;88(7):1407-15.

DiBattista JD, Randall JE, Bowen BW. Review of the round herrings of the genus Etrumeus (Clupeidae: Dussumieriinae) of Africa, with descriptions of two new species. Cybium. 2012;36(3):447-60.

Dragičević B, Anadoli O, Angel D, Benabdi M, Bitar G, Castriota L, et al. New Mediterranean biodiversity records (December 2019). Mediterr Mar Sci. 2019; 20(3):645-56 https://doi.org/10.12681/mms.20913.

EC (European Commission). Directive 2008/56/EC of the European Parliament and of the council of 17 June 2008, establishing a framework for community action in the field of marine environmental policy (marine strategy framework directive). Off J Eur Union. 2008;L164:19-40 https://eur-lex.europa. eu/legal-content/EN/TXT/HTML/?uri=CELEX:32008L0056\&from=EN.

EC (European Commission). Our life insurance, our natural capital: an EU biodiversity strategy to 2020: Communication from the Commission to the European Parliament, the Council, the Economic and Social Commitee and the Commitee of the Regions; 2011 https://eur-lex.europa.eu/legal-content/ EN/TXT/PDF/? uri=CELEX:52011DC0244\&from=EN.

EC (European Commission). Report from the commission to the European Parliament and the council. The mid-term review of the EU biodiversity strategy to 2020. Brussels: European Commission Report; 2014. p. 19.

Einav R, Israel A. Checklist of seaweeds from the Israeli Mediterranean: taxonomical and ecological approaches. Isr J Plant Sci. 2008;56(1-2):127-91.

Eltohamy WS, Alzeny A, Azab YA. Zooplankton of a stressed area in the Damietta coast of the Mediterranean Sea. Acta Adriat. 2017;58(2):245-60

EU Regulation. (EU). No 1143/2014 of the European Parliament and of the council on the prevention and management of the introduction and spread of invasive alien species. Off J Eur Union. 2014;L315:35-55.

Faulwetter S, Simboura N, Katsiaras N, Chatzigeorgiou G, Arvanitidis C. Polychaetes of Greece: an updated and annotated checklist. Biodivers Data J. 2017;5:e20997 https://doi.org/10.3897/BDJ.5.e20997.

Fernandez-Gonzalez V, Sanchez-Jerez P. Fouling assemblages associated with offcoast aquaculture facilities: an overall assessment of the Mediterranean Sea. Mediterr Mar Sci. 2017;18(1):87-96.

Ferrari FD, Orsi J. Oithona davisae, new species, and Limnoithona sinensis (Burckhardt, 1912)(Copepoda: Oithonidae) from the Sacramento-San Joaquin estuary, California. J Crustac Biol. 1984;4(1):106-26.

Ferrario J, Caronni S, Occhipinti-Ambrogi A, Marchini A. Role of commercial harbours and recreational marinas in the spread of non-indigenous fouling species. Biofouling. 2017;33(8):651-60.

Ferrario J, d'Hondt J-L, Marchini A, Occhipinti-Ambrogi A. From the Pacific Ocean to the Mediterranean Sea: Watersipora arcuata, a new non-indigenous bryozoan in Europe. Mar Biol Res. 2015;11(9):909-19 https://doi.org/10.1080/ 17451000.2015.1041531.

Fersi A, Dauvin JC, Pezy JP, Neifar L. Amphipods from tidal channels of the Gulf of Gabès (Central Mediterranean Sea). Mediterr Mar Sci. 2018;19(3): 430-43.

Filiz H, Sevingel N, Cerim H, Bilge G. First record of the blackbar hogfish, Bodianus speciosus (Actinopterygii: Perciformes: Labridae), in the Mediterranean Sea. Acta Ichthyol Piscat. 2019;49(4):399-402.

Fricke R, Golani D, Appelbaum-Golani B. Arnoglossus nigrofilamentosus n. sp., a new species of flounder (Teleostei: Bothidae) from off the Mediterranean coast of Israel, probably a new case of Lessepsian migration. Sci Mar. 2017; 81(4):457-65 https://doi.org/10.3989/scimar.04684.07A.

Furfaro G, De Matteo S, Mariottini P, Giacobbe S. Ecological notes of the alien species Godiva quadricolor (Gastropoda: Nudibranchia) occurring in Faro Lake (Italy). J Nat Hist. 2018;52(11-12):645-57.

Galil BS. Halimede tyche (Herbst, 1801) (Decapoda; Xanthoidea; Halimedinae) from the Mediterranean coast of Israel, with a review of the genus. J Crustac Biol. 2000;20:325-31

Galil BS, Gershwin LA, Zorea M, Rahav A, Rothman SB, Fine M, et al. Cotylorhiza erythraea Stiasny, 1920 (Scyphozoa: Rhizostomeae: Cepheidae), yet another erythraean jellyfish from the Mediterranean coast of Israel. Mar Biodivers. 2017a;47(1):229-35.

Galil BS, Levitt-Barmats YA, Lubinevsky H, Yudkovsky Y, Paz G, Rinkevich B. A record of Arcania brevifrons Chen, 1989 (Crustacea; Decapoda; Leucosiidae) from the Mediterranean coast of Israel. Biolnvasions Rec. 2017b;6(3):249-53.

Gerakaris V, Lardi PL, Issaris Y. First record of the tropical seagrass species Halophila decipiens Ostenfeld in the Mediterranean Sea. Aquat Bot. 2020;160: 103151 https://doi.org/10.1016/j.aquabot.2019.103151.

Gerovasileiou V, Akel E, Akyol O, Alongi G, Azevedo F, Babali N, et al. New Mediterranean Biodiversity Records (July, 2017). Mediterr Mar Sci. 2017;18(2): 355-84 https://doi.org/10.12681/mms.13771.

Gewing MT, Shenkar N. Monitoring the magnitude of marine vessel infestation by non-indigenous ascidians in the Mediterranean. Mar Pollut Bull. 2017; 121(1-2):52-9.

Giovos I, Bernardi G, Romanidis-Kyriakidis G, Marmara D, Kleitou P. First records of the fish Abudefduf sexfasciatus (Lacepède, 1801) and Acanthurus sohal (Forsskål, 1775) in the Mediterranean Sea. Biolnvasions Rec. 2018;7:205-10 https://doi.org/10.3391/bir.2018.7.2.14.

Giovos I, Kleitou P, Poursanidis D, Batjakas I, Bernardi G, Crocetta F, et al. Citizenscience for monitoring marine invasions and stimulating public engagement: a case project from the eastern Mediterranean. Biol Invasions. 2019;21(12): 3707-21 https://doi.org/10.1007/s10530-019-02083-w.

Golani D. First record of the flat needlefish Ablennes hians (Valenciennes, 1846) in the Mediterranean Sea (Osteichthyes, Beloniformes, Belonidae). Biolnvasions Rec. 2019;8(2):410-2.

Golani D, Ben TA. Two Red Sea flatheads (Platycephalidae) immigrants in the Mediterranean. Cybium. 1990;14(1):57-61.

Golani D, Salameh P, Sonin O. First record of the emperor angelfish, Pomacanthus imperator (Teleostei: Pomacanthidae) and the second record of the Spotbase burrfish Cyclichthys spilostylus (Teleostei: Diodontidae) in the Mediterranean. Aquat Invasions. 2010;5((1):Suppl 1):41-3.

Gönülal O, Lubinevsky H, Galil BS. The first indo-West Pacific rock shrimp (Crustacea, Decapoda, Sicyoniidae) in the Mediterranean Sea. Mar Biodivers Rec. 2016;5:39-42.

Goren L, Shefer S, Feldstein T. First record of the indo-Pacific species Iphione muricata Savigny in Lamarck, 1818 (Polychaeta: Iphionidae) from the Mediterranean Sea. Israel. Mediterr Mar Sci. 2017;18(1):134-7.

Gouillieux B, Sauriau PG. Laticorophium baconi (Shoemaker, 1934) (Crustacea: Amphipoda: Corophiidae: Corophiini): first record in European marine waters. Biolnvasions Rec. 2019;8(4):848-61.

Groom Q, Strubbe D, Adriaens T, Davis AJ, Desmet P, Oldoni D, et al. Empowering citizens to inform decision-making as a way forward to support invasive alien species policy. Citiz Sci Theory Pract. 2019;4:1-11 https://doi. org/10.5334/cstp.238.

Grossi L, Bertasi F, Trabucco B. New records of the alien polychaete worm Chaetozone corona (Polychaeta: Cirratulidae) in the Adriatic Sea. Acta Adriat. 2017;58(2):235-43.

Gueroun S, Molinero J, Piraino S, Daly YM. Population dynamics and predatory impact of the alien jellyfish Aurelia solida (Cnidaria, Scyphozoa) in the Bizerte lagoon (southwestern Mediterranean Sea). Mediterr Mar Sci. 2020;21(1):22-35 https://doi.org/10.12681/mms.17358.

Gürlek M, Erguden D, Atay B, Turan C. First record of Pomacanthus imperator (Bloch, 1787) from Turkish marine waters. Int J Nat Eng Sci. 2019;4(3):231-6.

Gürlek M, Ergüden D, Turan C. First record of elongate Bulleye Priacanthus prolixus in the Mediterranean Sea. NESciences. 2017;2(1):44-7.

Gvozdenović S, Nikolić M, Pešić V, Peraš I, Mandić M. First data on the alien Mollusc Fulvia fragilis (Forsskål in Niebuhr, 1775) (Cardiida: Cardiidae) from the Adriatic Sea. Acta zool bulg. 2019;71(2):267-72.

Halevy Y, Barchana D, Twina K, Lavi Y, Ben Zvi E, Rothman SB, et al. First records of Goniobranchus obsoletus from the Mediterranean coast of Israel. Triton. 2015;32:4-5.

Hamed O, Miled-Fathalli N, Chakroun-Marzouk N. First record of the Lessepsian migrant Pteragogus trispilus Randall, 2013 (Osteichthyes: Labridae) off the Tunisian coasts, Central Mediterranean Sea. Cah Biol Mar. 2018;59:115-9.

Harmelin JG. Alien bryozoans in the eastern Mediterranean Sea-new records from the coast of Lebanon. Zootaxa. 2014;3893(3):301-38.

Harmelin JG, Ostrovsky AN, Caceres-Chamizo JP, Sanner J. Bryodiversity in the tropics: taxonomy of Microporella species (Bryozoa, Cheilostomata) with personate maternal zooids from Indian Ocean, Red Sea and Southeast Mediterranean. Zootaxa. 2011;2798:1-30. 
Hoeksema BW, Ocaña VO. First record of the central indo-Pacific reef coral Oulastrea crispata in the Mediterranean Sea. Mediterr Mar Sci. 2014;15(2):42936 https://doi.org/10.12681/mms.751.

Hoffman R, Wynne MJ, Schils T, Lopez-Bautista J, Verbruggen H. Codium pulvinatum (Bryopsidales, Chlorophyta), a new species from the Arabian Sea, recently introduced into the Mediterranean Sea. Phycologia. 2017;57(1):79-89.

ICES. Working group on introductions and transfers of marine organisms (WGITMO). ICES Sci Rep. 2019;1:53.27 https://doi.org/10.17895/ices.pub.5569.

IMAP. Integrated monitoring and assessment Programme of the Mediterranean Sea and coast and related assessment criteria UNEP. Athens. 2017:52.

IMO (International Maritime Organization). International convention for the control and Management of Ships' ballast water and sediments, 2004. London: International Maritime Organization; 2004.

IMO (International Maritime Organization). Implementation of the BWM Convention. Resolution MEPC, vol. 71. London: International Maritime Organisation; 2017. p. 287

Insacco G, Zava B. Chlorurus rhakoura Randall \& Anderson, 1997 (Perciformes, Scaridae), an indo-Pacific fish new for the Mediterranean Sea. Mediterr Mar Sci. 2017;18(2):285-91.

IUCN (International Union for Conservation of Nature). Guidance for interpretation of CBD categories on introduction pathways. Technical note prepared by IUCN for the European Commission; 2017. .

Jensen HM, Panagiotidis P, Reker J. Delineation of the MSFD Article 4 Marine Regions and Subregions .2017 Version 1.0. European Environment Agency. Available online at: https://data.europa.eu/euodp/data/dataset/data_msfdregions-and-subregions.

Joseph H. Die pazifische und atlantische Medusengattung Gonionemus in der Adria. Naturwissenschaften. 1919;7(49):939-42.

Karachle P, Angelidis A, Apostolopoulos G, Ayas D, Ballesteros M, Bonnici C, et al. New Mediterranean biodiversity records (march 2016). Mediterr Mar Sci. 2016;17(1):230-52 https://doi.org/10.12681/mms.1684.

Karachle P, Foka MC, Crocetta F, Dulčić J, Dzhembekova N, Galanidi M, et al. Setting-up a billboard of marine invasive species in the ESENIAS area: current situation and future expectancies. Acta Adriat. 2017;58(3):429-58.

Khafage AR, Taha SM. First record of Xiphopenaeus kroyeri Heller, 1862 (Decapoda Penaeidae) in the southeastern Mediterranean. Egypt. Biolnvasions Rec. 2019; 8(2):392-9.

Kleitou P, Giovos I, Wolf W, Crocetta F. On the importance of citizen-science: the first record of Goniobranchus obsoletus (Rüppell and Leuckart, 1830) from Cyprus (Mollusca: Gastropoda: Nudibranchia). Biolnvasions Rec. 2019;8(2):252-7.

Korpinen S, Klančnik K, Peterlin M, Nurmi M, Laamanen L, Zupančič G, et al. Multiple pressures and their combined effects in Europe's seas. In: ETC/ICM technical report 4/2019: European topic Centre on inland, coastal and marine waters; 2019. p. 164. https://www.eionet.europa.eu/etcs/etc-icm/products/etc-icmreport-4-2019-multiple-pressures-and-their-combined-effects-in-europes-seas.

Kousteni V, Bakiu R, Benhmida A, Crocetta F, Di Martino V, Dogrammatzi A, et al. New Mediterranean biodiversity records 2019. Mediterr Mar Sci. 2019;20(1): 230-47 https://doi.org/10.12681/mms.19609.

Krupnik N, Paz G, Douek J, Lewinsohn E, Israel A, Carmel N, et al. Maggs ca. Native, invasive and cryptogenic Ulva species from the Israeli Mediterranean Sea: risk and potential. Mediterr Mar Sci. 2018;19(1):132-46.

Lakkis S. Considerations on the distribution of pelagic copepods in the eastern Mediterranean off the coast of Lebanon. Acta Adriat. 1976;18:41-52.

Lakkis S. Composition, diversité et successions de copépodes planctoniques des eaux libanaises (Méditerranée Orientale). Oceanol Acta. 1990;13(4):489-501.

Lakkis S, Toklu B, Zeidane R, Sarihan E. Importance of copepods in the zooplankton community of Iskenderoun Bay (north eastern Mediterranean). In: Tunis: 9th Int conf on copepoda; 2005.

Langeneck J, Crocetta F, Doumpas N, Giovos I, Piraino S, Boero F. First record of the non-native jellyfish Chrysaora cf. achlyos (Cnidaria: Pelagiidae) in the Mediterranean Sea. Biolnvasions Rec. 2019;8(3):608-13.

Langeneck J, Lezzi M, Mi DP, Musco L, Mc G, Castelli A, et al. Non-indigenous polychaetes along the coasts of Italy: a critical review. Mediterr Mar Sci. 2020: 238-75 https://doi.org/10.12681/mms.21860.

Langeneck J, Marcelli M, Bariche M, Azzurro E. Social networks allow early detection of non indigenous species: first record of the red drum Sciaenops ocellatus (Actinopterygii: Perciformes: Sciaenidae) in Italian waters. Acta Adriat. 2017:58(2):363-8.

Latombe G, Pyšek P, Jeschke JM, Blackburn TM, Bacher S, Capinha C, et al. A vision for global monitoring of biological invasions. Biol Conserv. 2017;213: 295-308 https://doi.org/10.1016/j.biocon.2016.06.013.
Lezzi M, Del Pasqua M, Pierri C, Giangrande A. Seasonal non-indigenous species succession in a marine macrofouling invertebrate community. Biol Invasions. 2018;20(4):937-61.

Lezzi M, Giangrande A. New species of Streblosoma (Thelepodidae, Annelida) from the Mediterranean Sea: S. pseudocomatus sp.nov., S. nogueirai sp. nov. and S. hutchingsae sp. nov. J Nat Hist. 2018;52:2857-73.

Lipej L, Acevedo I, Akel E, Anastasopoulou A, Angelidis A, Azzurro E, et al. 2018 New Mediterranean biodiversity records. (March 2017). Mediterr Mar Sci. 2017;18(1):179-201 https://doi.org/10.12681/mms.2068.

Lipej L, Mavrič B, Žiza V, Dučić J. The largescaled therapon Terapon theraps: a new indo-pacific fish in the Mediterranean Sea. J Fish Biol. 2008;73:1819-22.

Lubinevsky H, Galil BS, Bogi C. First record of Gari pallida (Deshayes, 1855)(Mollusca: Bivalvia: Psammobiidae) in the Mediterranean Sea. Biolnvasions Rec. 2018;7(4):415-9.

Maas O. Die Scyphomedusen der Siboga-expedition. [Siboga-expeditie 11.]. Leiden: E.J. Brill; 1903. viii + 91 pp. + plates I-XII.

Maggio T, Allegra A, Bosch-Belmar M, Cillari T, Cuttitta A, Falautano M, et al. Molecular identity of the non-indigenous Cassiopea sp. from Palermo harbour (Central Mediterranean Sea). J Mar Biol Assoc UK. 2019:99:1765-73.

Maidanou M, Koulouri P, Arvanitidis C, Koutsoubas D, Dounas C. Macrobenthic assemblage structure associated with a Caulerpa prolifera meadow in the eastern Mediterranean Sea (Elounda Bay, Crete Island). Reg Stud Mar Sci. 2017:14:1-14

Malt SJ, Lakkis S, Ziedane R. The copepod genus Oncaea (Poecilostomatoida) from the Lebanon: taxonomic and ecological observations. J Plankton Res. 1989;11:949-69.

Marchini A, Ferrario J, Occhipinti-Ambrogi A. Confirming predictions: the invasive isopod laniropsis serricaudis Gurjanova, 1936 (Crustacea: Peracarida) is abundant in the lagoon of Venice (Italy). Acta Adriat. 2016;57(2):331-6.

Mariani S, Ocaña Vicente O, Lopez-Sendino P, Garcia M, Ricart AM, Garrabou J, et al. The zooxanthellate scleractinian coral Oulastrea crispata (Lamarck, 1816), an overlooked newcomer in the Mediterranean Sea? Mediterr Mar Sci. 2018; 19(3):589-97 https://doi.org/10.12681/mms.16986.

McKinley DC, Miller-Rushing AJ, Ballard HL, Bonney R, Brown H, Cook-Patton SC, et al. Citizen science can improve conservation science, natural resource management, and environmental protection. Biol Conserv. 2017;208:15-28 https://doi.org/10.1016/j.biocon.2016.05.015.

Merella P, Casu M, Garippa G, Pais A. Lessepsian fish migration: genetic bottlenecks and parasitological evidence. J Biogeogr. 2010;37(5):978-80 https://doi.org/10.1111/j.1365-2699.2010.02272.x.

Merella P, Farjallah S, Pais A, Follesa MC, Garippa G. Fistularia commersonil Ruppell, 1835: a Lessepsian host carrier of indo-Pacific parasites into the Mediterranean Sea. In: Xth European multicolloquium of Parassitologia, vol. 49; 2007. p. 249.

Micali P, Siragusa F, Agamennone F, Germanà A, Sbrana C. Karpathos Island (Greece) and its indo-Pacific alien species. Part 1. Boll Malacol. 2017;53(1):40-9.

Mienis HK, Rittner O, Shefer S, Feldstein T, Yahel R. First record of the indo pacific Isognomon legumen from the Mediterranean coast of Israel (Mollusca, Bivalvia, Isognomidae). Triton. 2016;33:9-11.

Miladi R, Manghisi A, Minicante SA, Genovese G, Abdelkafi S, Morabito M. A DNA barcoding survey of UIva (Chlorophyta) in Tunisia and Italy reveals the presence of the overlooked alien U. ohnoi. Cryptogam Algol. 2018;39(1):85-107.

Mineur F, Belsher T, Johnson MP, Maggs CA, Verlaque M. Experimental assessment of oyster transfers as a vector for macroalgal introductions. Biol Conserv. 2007;137(2):237-47.

Minos G, Imsiridou A, Economidis PS. First record of Terapon theraps (Terapontidae) in the Aegean Sea (Greece). Cybium. 2012;36(2):401-2.

Moraitou-Apostolopoulou M. Sur la présence en mer Égèe d'Arietellus pavoninus copépode pelagique cité pour la première fois en Méditerranée. Biol gallohellenica. 1969:2:189-91.

Morri C, Bianchi CN, Cocito S, Peirano A, De Biase AM, Aliani S, et al. Biodiversity of marine sessile epifauna at an Aegean island subject to hydrothermal activity: Milos, eastern Mediterranean Sea. Mar Biol. 1999;135:729-39.

Moussa H, Wynne MJ, Hassoun M, Salhi G, Zbakh H, Kazzaz M, et al. On the occurrence of three red algal species new to the Mediterranean Sea in AlHoceima National Park (Morocco). Bot Mar. 2015;58(6):499-509.

Moussa R, Kapiris K, Zenetos A. Brachyuran diversity along Mediterranean Egypt, with the addition of a new introduced species. Cah Biol Mar. 2016;57:43-9.

Munari C, Bocchi N, Parrella P, Granata T, Moruzzi L, Massara F, et al. The occurrence of two morphologically similar Chaetozone (Annelida: Polychaeta: Cirratulidae) 
species from the Italian seas: Chaetozone corona Berkeley \& Berkeley, 1941 and C. carpenteri McIntosh, 1911. Eur Zool J. 2017;84(1):541-53.

Munilla T, San VC. Suprabenthic biodiversity of Catalan beaches (NW Mediterranean). Acta Oecol. 2005;27(2):81-91.

Murina W. New abyssal species of echiurans from the Pacific and Atlantic oceans. Zoological J (USSR). 1976:55:837-44.

Nordsieck F. A new Neritidae in the Mediterranean. La Conchiglia. 1973;5(7-8):4.

Nykjaer L. Mediterranean Sea surface warming 1985-2006. Clim Res. 2009;39:11-7.

Occhipinti Ambrogi A, d'Hondt JL. Introduzione di specie alloctone in Laguna di Venezia: Celleporella carolinensis Ryland 1979 (Bryozoa: Ascophora). Boll Mus civ St Nat Venezia. 1996;46:53.

O'Donoghue $\mathrm{CH}$, White KM. A collection of marine molluscs, mainly opisthobranchs from Palestine. Proc Malac Soc Lond. 1940;24:92-6.

Osca D, Tanduo V, Tiralongo F, Giovos I, Almabruk SA, Crocetta F, et al. The indoPacific sergeant Abudefduf vaigiensis (Quoy \& Gaimard, 1825)(Perciformes: Pomacentridae) in Libya, south-Central Mediterranean Sea. J Mar Sci Eng. 2020;8(1):14.

Ounifi Ben Amor K, Ben Amor MM, Rifi M, Ben Souissi J. Diversity of crustacean species from Tunis Southern Lagoon (Central Mediterranean) after an ecological restoration. Cah Biol Mar. 2017;58:49-57.

Ozbilgin YD, Kalecik E, Gücü AC. First record of humpback dolphins in Mersin Bay, the eastern Mediterranean. Turkey Turk J Fish Aquat Sc. 2018;18(1):187-90.

Öztürk B, Bitlis B, Doğan A, Türkçü N. Alien marine molluscs along the Turkish coast, with a new record of Varicopeza pauxilla (a. Adams, 1855)(Mollusca: Gastropoda) from the Mediterranean Sea. Acta Zool Bulgar. 2017;1:83-92.

Patania A, Mutlu E. First occurrence of knight rock shrimp, Sicyonia lancifer (Olivier, 1811)(Decapoda: Sicyoniidae) in the Mediterranean Sea. Mediterr Mar Sc. $2016 ; 17(1): 144-6$.

Payne NL, Smith JA, van der Meulen DE, Taylor MD, Watanabe YY, Takahashi A, et al. Temperature dependence of fish performance in the wild: links with species biogeography and physiological thermal tolerance. Funct Ecol. 2016; 30:903-12.

Paz-Sedano S, Tanduo V, Yonow N, Yokeş MB, Kletou D, Crocetta F. Baeolidia moebii Bergh, 1888 (Mollusca: Gastropoda: Nudibranchia) is spreading in the eastern Mediterranean Sea. Reg Stud Mar Sci. 2019;32:100830.

Picard J. Notes Sur les hydroméduses méditerranéennes de la famille des Olindiadidae. Arch Zool Exp Gen 88 notes et revue. 1951;1:39-48.

Piraino S, Aglieri G, Martell L, Mazzoldi C, Melli V, Milisenda G, et al. Pelagia benovici sp. nov. (Cnidaria, Scyphozoa): a new jellyfish in the Mediterranean Sea. Zootaxa. 2014;3794(3):455-68 https://doi.org/10.11646/zootaxa.3794.3.7.

Poli JX. Testacea utriusque Siciliae eorumque historia et anatome tabulis aeneis illustrata a losepho Xaverio Poli. Tomus. 1791;1:1-11.

Powell NA. Indo-Pacific Bryozoa new to the Mediterranean coast of Israel. Isr J Zool. 1969;18:157-68.

Rabitsch W, Genovesi P, Scalera R, Biała K, Josefsson M, Essl F. Developing and testing alien species indicators for Europe. J Nat Conserv. 2016;29:89-96.

Radashevsky V, Pankova V, Malyar V, Neretina T, Wilson R, Worsfold T, et al. Molecular analysis and new records of the invasive polychaete Boccardia proboscidea (Annelida: Spionidae). Mediterr Mar Sci. 2019;20(2):393-408 https://doi.org/10.12681/mms.20363.

Rafrafi-Nouira S, Ounifi-Ben Amor K, Ben Amor MM. Abundant records of red-eye round herring Etrumeus golanii (Osteichthyes: Clupeidae) from the Tunisian coast (Central Mediterranean). Annales - Ser Hist Nat. 2017;27:65-8.

Ramadan SE. Ecological and systematic studies on the marine fouling of the northern part of the Suez Canal. Ph.D. Thesis: Mansura University, Egypt; 1986. p. 420.

Ramadan SE, Dowidar NM, Khalil AN, Elsonbaty SM. Redescription of three new records of isopoda (Crustacea) associated with fouling communities in the eastern harbour of Alexandria Egypt. Bull Nat Inst Oceanogr Fish (Egypt), ARE. 1998;24:197-220.

Rania AA, Rehab RA. Some studies on parasitic isopods of some marine fishes. Egypt J Chem Environ Health. 2015;1 (1):400-20.

Rizgalla J, Shinn AP, Crocetta F. The alien fissurellid Diodora ruppellii (GB Sowerby I, 1835): a first record for Libya from Tripoli harbour. Biolnvasions Records. 2019;8(4):813-7.

Rothman SB, Mienis HK, Galil BS. Alien facelinid nudibranchs in the eastern Mediterranean: first report of Phidiana militaris (Alder and Hancock, 1864) and report of Caloria indica (Bergh, 1896) 30 years after its previous sighting. Biolnvasions Rec. 2017;6(2):125-8.

Roy HE, Adriaens T, Aldridge DC, Bacher S, JDD B, Blackburn TM, et al. Invasive alien species - Prioritising prevention efforts through horizon scanning ENV.B. 2/ETU/2014/0016 European Commission; 2015.
Saad A, Alkusairy H, Sabour W. First record of the emperor angelfish, Pomacanthus imperator (Acthenoptergii: Pomacanthidae) in the Syrian coast (eastern Mediterranean). Mar Biodivers Rec. 2018;11(1):16.

Saiz E, Calbet A, Broglio E. Effects of small-scale turbulence on copepods: the case of Oithona davisae. Limnol Oceanogr. 2003;48:1304-11.

Salem O. Parasites of invasive fishes and their impact on the western coast of LibyaMSc. Thesis. Libya: Tripoli University; 2017.

Samaan AA, Ghobashy AF, Aboul Ezz SM. The benthic fauna of Lake Burollus. 1. Community composition and distribution of the total fauna. Bull Nat Inst Oceanogr Fish Egypt. 1989;15:217-24.

Sarno D, Zingone A. MARECHIARA-phytoplankton long-term time-series (19842006) at the fixed coastal station in the Gulf of Naples, southern Tyrrhenian Sea; 2008. https://doi.org/10.1594/PANGAEA.701471.

Scalera R. How much is Europe spending on invasive alien species? Biol Invasions. 2010;12(1):173-7.

Schellenberg A. Report on Amphipoda. Zoological results of the Cambridge expedition to the Suez Canal, 1924. Trans Zool Soc London. 1928;22: 633-92.

Scuderi D, Eernisse DJ. A new alien limpet for the Mediterranean: Lottia sp. (Patellogastropoda Lottiidae). Biodivers J. 2016;7(2):287-93.

Scuderi D, Viola A. The last alien reaching Sicily: Isognomon legumen (Gmelin, 1791) (Mollusca Bivalvia Isognomonidae). Biodivers J. 2019;10(4): 337-42.

Seebens H, Blackburn TM, Dyer EE, Genovesi P, Hulme PE, Jeschke JM, et al. No saturation in the accumulation of alien species worldwide. Nat Commun. 2017;8(1):1-9.

Seebens H, Essl F, Dawson W, Fuentes N, Moser D, Pergl J, et al. Global trade will accelerate plant invasions in emerging economies under climate change. Glob Chang Biol. 2015;21(11):4128-40.

Seregin SA, Popova EV. Different-scale variations in the abundance and species diversity of metazoan microzooplankton in the coastal zone of the Black Sea. Water Res. 2019;46(5):769-79.

Servello G, Andaloro F, Azzurro E, Castriota L, Catra M, Chiarore A, et al. Marine alien species in Italy: a contribution to the implementation of descriptor D2 of the marine strategy framework directive. Mediterr Mar Sci. 2019;20(1):1-48 https://doi.org/10.12681/mms.18711.

Seyhan D, Irmak E, Fricke R. Diplogrammus randalli (Pisces: Callionymidae), a new Lessepsian migrant recordedfrom the Mediterranean Sea. Mediterr Mar Sci. 2017;18(1):1-3 https://doi.org/10.12681/mms.1948.

Simon CA, van Niekerk HH, Burghardt I, ten Hove HA, Kupriyanova EK. Not out of Africa: Spirobranchus kraussii (Baird, 1865) is not a global fouling and invasive serpulid of IndoPacific origin. Aquat Invasions. 2019;14(2):221-49 https://doi. org/10.3391/ai.2019.14.2.05.

SPA/RAC-UN Environment/MAP. In: Ramos-Esplá AA, Bitar G, Forcada A, Valle C, Ocaña O, Sghaier YR, Samaha Z, Limam A, editors. Ecological characterization of potential new MPAs in Lebanon: Batroun, Medfoun and Byblos. Tunis: SPA/RAC. MedMPA Network Project; 2017. p. 120p.+ annexes.

Spagnolo A, Auriemma R, Bacci T, Balković I, Bertasi F, Bolognini L, et al. Nonindigenous macrozoobenthic species on hard substrata of selected harbours in the Adriatic Sea. Mar Pollut Bull. 2019;147:150-8.

Spanier E, Friedmann E. The collection of an exuvia identified as Panulirus longipes longipes (a. Milne-Edwards, 1868) from off Haifa, Israel. Mediterr. Mar Sci. 2019;20(1):227-9 https://doi.org/10.12681/mms.18914.

Stamouli C, Akel E, Azzurro E, Bakiu R, Bas A, Bitar G, et al. New Mediterranean biodiversity records (December 2017). Mediterr Mar Sci. 2017;18(3):534-56 https://doi.org/10.12681/mms.15823.

Steger J, Stockinger M, Ivkić A, Galil BS, Albano PG. New records of nonindigenous molluscs from the eastern Mediterranean Sea. Biolnvasions Rec. 2018;7(3):245-57.

Stern N, Badreddine A, Bitar G, Crocetta F, Deidun A, Dragičević B, et al. New Mediterranean biodiversity records 2019. Mediterr Mar Sci. 2019;20(2):409-26 https://doi.org/10.12681/mms.20602.

Stern N, Paz G, Yudkovsky Y, Lubinevsky H, Rinkevich B. The arrival of a second 'Lessepsian sprinter'? A first record of the red cornetfish Fistularia petimba in the eastern Mediterranean. Mediterr Mar Sci. 2017;18(3):524-8.

Stuart-Smith RD, Edgar GJ, Bates AE. Thermal limits to the geographic distributions of shallow-water marine species. Nat Ecol Evol. 2017;1:1846-52.

Sunday JM, Bate AE, Dulvy NK. Global analysis of thermal tolerance and latitude in ectotherms. Nat Clim Chang. 2012;2:686-90.

Tamsouri MN, Benchoucha S, Idhalla M, El Aamri F. Etrumeus golanii (Actinopterygii: Clupeiformes: Dussumieriidae) a new Lessepsian migrant 
recorded in Morocco, Alboran Sea (south-West Mediterranean). Acta Ichthyol Piscat. 2019:49(1):43-7.

Tardent P. Capture d'un Abudefduf saxatilis vaigiensis Q. und G. (Pisces, Pomacentridae) dans le Golfe de Naples. Rev Suisse Zool. 1959;66:347-51.

Terbıyık Kurt T. Contribution and acclimatization of the swarming tropical copepod Dioithona oculata (Farran, 1913) in a Mediterranean coastal ecosystem. Turk J Zool. 2018;42(5):567-77.

Terbıyık Kurt T, Beşiktepe Ş. First distribution record of the invasive copepod Oithona davisae Ferrari and Orsi, 1984, in the coastal waters of the Aegean Sea. Mar Ecol. 2019;40(3):e12548 https://doi.org/10.1111/maec.12548.

Terbıyık Kurt T, Polat S. Introduction of a new indo-Pacific marine cladoceran to the Mediterranean Sea. Mediterr Mar Sci. 2017;18(3):517-23.

Tilbrook KJ. Description of Hippopodina feegeensis and three other species of Hippopodina Levinsen, 1909 (Bryozoa: Cheilostomatida). J Zool. 1999;247(4):449-56.

Tilbrook KJ. Cheilostomatous Bryozoa from the Solomon Islands. In: Chaney HW, editor. Santa Barbara Museum of Natural History. Studies in biodiversity; 2006. p. 4.

Tiralongo F, Lipari R, Mancini E. A new exotic fish for the Mediterranean Sea: Chaetodon auriga Forsskål, 1775 (Perciformes: Chaetodontidae). Mediterr Mar Sci. 2018;19(3):491-3

Trilles JP, Bariche M. First record of the indo-Pacific Cymothoa indica (Crustacea, isopoda, Cymothoidae), a Lessepsian species in the Mediterranean Sea. Acta Parasitol. 2006;51(3):223-30.

Tsadok R, Rubin-Blum M, Shemesh E, Tchernov D. On the occurrence and identification of Abudefduf saxatilis (Linnaeus, 1758) in the easternmost Mediterranean Sea. Aquat Invasions. 2015;10(1):101-5.

Tsiamis K, Azzurro E, Bariche M, Çinar ME, Crocetta F, De Clerck O, et al. Prioritizing marine invasive alien species in the European Union through horizon scanning. Aquat Conserv. 2020;30(4):794-845.

Tsiamis K, Gervasini E, D'Amico F, Deriu I, Katsanevakis S, Crocetta F, et al. The EASIN editorial board: quality assurance, exchange and sharing of alien species information in Europe. Manag Biol Invasion. 2016;7(4):321-8.

Tsiamis K, Palialexis A, Stefanova K, Gladan ŽN, Skejić S, Despalatovi M, et al. Nonindigenous species refined national baseline inventories: a synthesis in the context of the European Union's marine strategy framework directive. Mar Pollut Bull. 2019;145:429-35.

Turk T, Furlan B. New records of indo-Pacific and Atlantic mollusc species (Opisthobranchia) in the eastern Mediterranean and Adriatic Sea. Annales Ser Hist Nat. 2011;21(1):5-10.

Ulman A, Ferrario J, Occhpinti-Ambrogi A, Arvanitidis C, Bandi A, Bertolino M, et al. A massive update of non-indigenous species records in Mediterranean marinas. PeerJ. 2017;5:e3954 https://doi.org/10.7717/peerj.3954.

Uysal Z, Kideys AE, Shmeleva AA, Zagorodnyaya JA, Gubanova AD. Checklist of copepods (Calanoida and Podoplea) from the northern Levantine basin shelf waters. Hydrobiologia. 2002;482:15-21.

Vanderhoeven S, Adriaens T, Desmet P, Strubbe D, Backeljau T, Barbier Y, et al. Tracking invasive alien species (TrlAS): building a data-driven framework to inform policy. Res Ideas Outcomes. 2017;3:e13414 https://doi.org/10.3897/rio.3.e13414.

Velasquez X, Bolanos DM, Benayahu Y. New records of cotylean flatworms (Platyhelminthes: Polycladida: Rhabditophora) from coastal habitats of Israel. Zootaxa. 2018;4438(2):237-60.

Vella A, Agius Darmanin S, Vella N. The first records of indo-Pacific sergeant Abudefduf vaigiensis (Quoy \& Gaimard, 1825) and further notes on the occurrence of sergeant major a. saxatilis (Linnaeus, 1758) in Malta: expanding populations of an invasive genus in the Mediterranean Sea. J Black Sea/ Mediter Envir. 2016;22(1):1-5.

Verlaque $M$, Langar $H$, Hmida AB, Pergent C, Pergent G. Introduction of a new potential invader into the Mediterranean Sea: the indo-Pacific Avrainvillea amadelpha (Montagne) a. Gepp \& ES Gepp (Dichotomosiphonaceae, Ulvophyceae). Cryptogam Algol. 2017:38(3):267-82.

Viard F, Roby C, Turon X, Bouchemousse S, Bishop J. Cryptic diversity and database errors challenge non-indigenous species surveys: an illustration with Botrylloides spp. in the English Channel and Mediterranean Sea. Front Mar Sci. 2019:6:615.

Vidjak O, Bojanić N, de Olazabal A, Benzi M, Brautović I, Camatti E, et al. Zooplankton in Adriatic port environments: indigenous communities and non-indigenous species. Mar Pollut Bull. 2019;147:133-49 https://doi.org/10. 1016/j.marpolbul.2018.06.055.

Wolf MA, Buosi A, Juhmani ASF, Sfriso A. Shellfish import and hull fouling as vectors for new red algal introductions in the Venice lagoon. Estuar Coast Shelf Sci. 2018;215:30-8.
WoRMS Editorial Board. World register of marine species; 2019 Available from http:// www.marinespecies.org at VLIZ. Accessed 2019-12-31. https:/doi.org/10.14284/170.

Yapici HH, Yapici S, Agdamar S, Acar U. Occurrence of the Erythrean invader Pteragogus pelycus Randall, 1981 (Teleostei: Labridae) in the eastern Aegean Sea. J Appl Ichthyol. 2015;31(3):538-40.

Yokeş M, Andreou V, Bakiu R, Bonanomi S, Camps J, Christidis G, et al. New Mediterranean biodiversity records (November 2018). Mediterr Mar Sci. 2018; 19(3):673-89 https://doi.org/10.12681/mms.19386.

Yokeş MB, Dalyan C, Ünsal Karhan S, Demir V, Tural U, Kalkan E. Alien opisthobranchs from Turkish coasts: first record of Plocamopherus tilesii Bergh, 1877 from the Mediterranean. Triton; 25 March; 2012. p. 3-5.

Zagami G, Brugnano C, Granata A, Guglielmo L, Minutoli R, Aloise A. Biogeographical distribution and ecology of the planktonic copepod Oithona davisae: rapid invasion in lakes Faro and Ganzirri (Central Mediterranean Sea). In: Trends in Copepod Studies-Distribution, Biology and Ecology; 2018. p. 59-82.

Zenetos A. Progress in Mediterranean bioinvasions two years after the Suez Canal enlargement. Acta Adriat. 2017;58(2):347-58 https://doi.org/10.32582/aa.58.2.13.

Zenetos A. Mediterranean Sea: 30 years of biological invasions (1988-2017). In: 1st Mediterranean symposium on the non-indigenous species; 2019. p. 13.

Zenetos A, Çinar ME, Crocetta F, Golani D, Rosso A, Servello G, et al. Uncertainties and validation of alien species catalogues: the Mediterranean as an example. Estuar Coast Shelf S. 2017:191:171-87.

Zenetos A, Gofas S, Russo G, Templado J, Briand F. CIESM atlas of exotic species in the Mediterranean, vol. 3. Monaco: MolluscsCIESM Publishers; 2004. p. 376.

Zenetos A, Gofas S, Verlaque M, Çinar ME, Raso JG, Bianchi CN, Morri C, Azzurro E, Bilecenoglu M, Froglia C, Siokou I, Violanti D, Sfriso A, San Martin G, Giangrande A, Katagan T, Ballesteros E, Ramos-Espla A, Mastrototaro F, Ocana O, Zingone A, Gambi M, Streftaris N. Alien species in the Mediterranean Sea by 2010. A contribution to the application of European Union's marine strategy framework directive (MSFD). Part I. spatial distribution. Mediterr Mar Sci. 2010;11(2):381 https://doi.org/10.12681/mms.87.

Zenetos A, Gratsia E, Cardoso AC, Tsiamis K. Time lags in reporting of biological invasions: the case of Mediterranean Sea. Mediterr Mar Sci. 2019;20(2):469-75 https://doi.org/10.12681/mms.20716.

Zenetos A, Koutsogiannopoulos D, Ovalis P, Poursanidis D. The role played by citizen scientists in monitoring marine alien species in Greece. Cah Biol Mar. 2013:54:419-26.

Zenetos A, Meriç E, Verlaque M, Galli P, Boudouresque CF, Giangrande A, et al. Additions to the annotated list of marine alien biota in the Mediterranean with special emphasis on foraminifera and parasites. Mediterr Mar Sci. 2008; 9(1):119-66 https://doi.org/10.12681/mms.146.

\section{Publisher's Note}

Springer Nature remains neutral with regard to jurisdictional claims in published maps and institutional affiliations.

Ready to submit your research? Choose BMC and benefit from:

- fast, convenient online submission

- thorough peer review by experienced researchers in your field

- rapid publication on acceptance

- support for research data, including large and complex data types

- gold Open Access which fosters wider collaboration and increased citations

- maximum visibility for your research: over $100 \mathrm{M}$ website views per year

At BMC, research is always in progress.

Learn more biomedcentral.com/submissions 